\title{
Sensitivity assessment of bathymetry and choice of tidal constituents on tidal stream energy resource characterisation in the Gulf of California, Mexico
}

Mejia-Olivares, Carlos; Haigh, I.D.; Lewis, Matthew; Neill, Simon

\section{Applied Ocean Research}

Published: 01/09/2020

Peer reviewed version

Cyswllt i'r cyhoeddiad / Link to publication

Dyfyniad o'r fersiwn a gyhoeddwyd / Citation for published version (APA):

Mejia-Olivares, C., Haigh, I. D., Lewis, M., \& Neill, S. (2020). Sensitivity assessment of bathymetry and choice of tidal constituents on tidal stream energy resource characterisation in the Gulf of California, Mexico. Applied Ocean Research.

\footnotetext{
Hawliau Cyffredinol / General rights

Copyright and moral rights for the publications made accessible in the public portal are retained by the authors and/or other copyright owners and it is a condition of accessing publications that users recognise and abide by the legal requirements associated with these rights.

- Users may download and print one copy of any publication from the public portal for the purpose of private study or research.

- You may not further distribute the material or use it for any profit-making activity or commercial gain

- You may freely distribute the URL identifying the publication in the public portal ?
}

Take down policy

If you believe that this document breaches copyright please contact us providing details, and we will remove access to the work immediately and investigate your claim. 
Sensitivity assessment of bathymetry and choice of tidal constituents on tidal-stream energy resource characterisation in the Gulf of California, Mexico.

4

\section{Corresponding author}

E-mail address: carlos.mejia-olivares@noc.soton.ac.uk (Carlos Joel Mejia-Olivares).

Ocean and Earth Science, National Oceanography Centre, University of Southampton,

European Way, Southampton, SO14 3ZH, U.K.

Submit to Applied Ocean Research.

Revised version submitted June 2020 


\section{Abstract}

There has been a significant increase in the number of published tidal-stream energy resource assessments in recent years due to the growing availability of open-source hydrodynamic models, and freely available data for model bathymetry (e.g. GEBCO_2014 and ETOPO) and boundary conditions (e.g. TPXO, FES, EOT). This study examines how the choice of bathymetry and tidal constituents affects the quantification of a tidal-stream energy resource, by conducting sensitivity tests for the Gulf of California. We find that the mean KPD (Kinetic Power Density) and annual mean power are significantly underestimated when using just GEBCO_2014 or ETOPO bathymetry data sources on their own. For the Midriff region, between San Lorenzo and San Esteban Islands (herein the San Lorenzo Passage), the annual mean power potential was estimated to be around $50 \mathrm{MW}$ when using freely available bathymetry data, while the annual mean power increased to $\sim 200 \mathrm{MW}$ when using a bespoke dataset that was a combination of GEBCO and higher-resolution bathymetry provided by CICESE (The Centre for Scientific Research and Higher Education at Ensenada). Current speeds reduce from $2.4 \mathrm{~m} / \mathrm{s}$ when using highresolution to around $1.2 \mathrm{~m} / \mathrm{s}$ and $0.8 \mathrm{~m} / \mathrm{s}$ when using open source bathymetry products. Finally, we compared the estimated energy using tidal levels predicted from 29 tidal constituents compared with simulations that included just the principal semi-diurnal lunar $\left(\mathrm{M}_{2}\right)$ and solar $\left(\mathrm{S}_{2}\right)$ constituents. The annual mean KPD reduced by almost $1 / 3^{\text {rd }}$ in the San Lorenzo Passage, when just considering $M_{2}$ and $S_{2}$ constituents, suggesting that diurnal and higher order harmonic constituents are important for accurate resource assessments in this region.

Key words: Tidal-stream energy, bathymetry, sensitivity tests, annual mean power, GEBCO, ETOPO, Gulf of California, Mexico

\section{Introduction}

Over the last two decades, there has been increased interest in tidal energy exploitation [1]. Tidal energy offers many benefits compared to other sources of renewable energy, because of the regular and predictable nature of tides [2]. There are two main ways of harnessing tidal energy: (1) tidal range via the use of tidal barrages or lagoons; and (2) tidal current (tidal-stream). Tidal barrages or lagoons are major constructions that are generally associated with relatively high environmental impacts [3]. In contrast, tidal-stream generators make use of the kinetic energy of moving water to power turbines [2], similar in principle to wind turbines. The main differences are the flow density and the thrust that each device is capable of tolerating under regular operational conditions. The kinetic energy in Marine current devices is defined as the movement of the total velocity of the current across the swept area of a horizontal axis device that can be used to generate electricity with an attached generator [1] and [4].

This paper focuses on tidal-stream energy, which has been assessed in a growing number of published studies for different sites around the world using a variety of modelling techniques and tidal hydrodynamic models. A wide range of different bathymetric sources (e.g., global, regional and local bathymetry products, boat surveys and/or bathymetry charts) have been used to configure the underlying numerical model grids. Details of the studies that mention the specific bathymetric data sources they used, are summarised in Appendix A Table 1; a few of them 
combinations of tidal constituent when conducting energy resource assessments. For example, several past studies have investigated the variability of the available tidal-stream energy using just the $\mathrm{M}_{2}$ tidal constituent e.g. for the Johnstone Strait, Vancouver Island [5], Masset Sound Haida Gwaii in Canada [6] and Pentland Firth, in the UK [7]. Therefore, here we consider it pertinent to conduct sensitivity testing comparing energy resource estimates calculated from numerical hydrodynamic simulations based on a variety of free global bathymetry products, and higher resolution datasets, and considering considered different numbers and combinations of tidal constituent. We focus on the Gulf of California, (Mexico) herein GC, building on an earlier study by [8].

The GC, located at the northwest of Mexico City (capital of Mexico) is about $1100 \mathrm{~km}$ in length. Furthermore, the GC is between 48 and $240 \mathrm{~km}$ in width between the Baja California peninsula and the mainland. The GC is divided into three main regions: (1) the northern region; (2) the central or Midriff region; and (3) the southern region. The bathymetry in the GC varies from around $200 \mathrm{~m}$ in the northern Gulf to 2,500-3,600 m depth at the entrance area with the Pacific Ocean. Peak spring tidal currents exceed $1.5 \mathrm{~m} / \mathrm{s}$ around the Midriff Island in the Gulf of California [9] and [10]. Therefore, this region, where water depths are around 400 to $600 \mathrm{~m}$, has potential for tidal-stream energy extraction. The first theoretical tidal-stream energy resource quantification was conducted recently by [8]. The GC is relatively deep, and diurnal tidal constituents are typically larger in the northern GC rather than at the entrance of the GC (Fig. 1) where water depths are approximately between 2000 and $3000 \mathrm{~m}$ depth. A study by [8] found that the resource characterisation in this region contrasts considerably from previously identified tidal-stream sites around the world, where water depth is typically less than $80 \mathrm{~m}$. Currently developments of first-generation turbine requires tidal-stream flows $>2 \mathrm{~m} / \mathrm{s}[11]$ and a maximum depth of $<80$ $\mathrm{m}[12][13]$.

The overall aim of this paper is to examine how choice of bathymetry product and number and combination of tidal constituents affects the quantification of the tidal-stream energy resource for the GC. We undertake sensitivity tests in which we estimate and compare the maximum theoretical undisturbed mean KPD and annual mean power output calculated from hydrodynamic model runs that used: (1) just GEBCO_2014 bathymetry data [14]; (2) just the ETOPO bathymetry data [15]; and (3) GEBCO_2014 data merged with higher resolution data from CICESE (The Centre for Scientific Research and Higher Education at Ensenada), for the upper part of the GC. We then consider how different numbers of tidal constituents affects the quantification of the tidal-stream energy resource for the GC. Crucially, and as explained in more detail below, we do not vary the number of tidal constituents at the model boundary when we run the model for a 1 month simulation; we just vary the number of

104 tidal constituents we use to predict a complete year of tidal currents for estimating the tidal resource at different sites. The structure of the paper is as follows: in Section 2 we briefly describe the numeral model set up and configuration. The methodology is then outlined in Section 3. The results are presented in Section 4 and finally conclusions are given in Section 5 . 

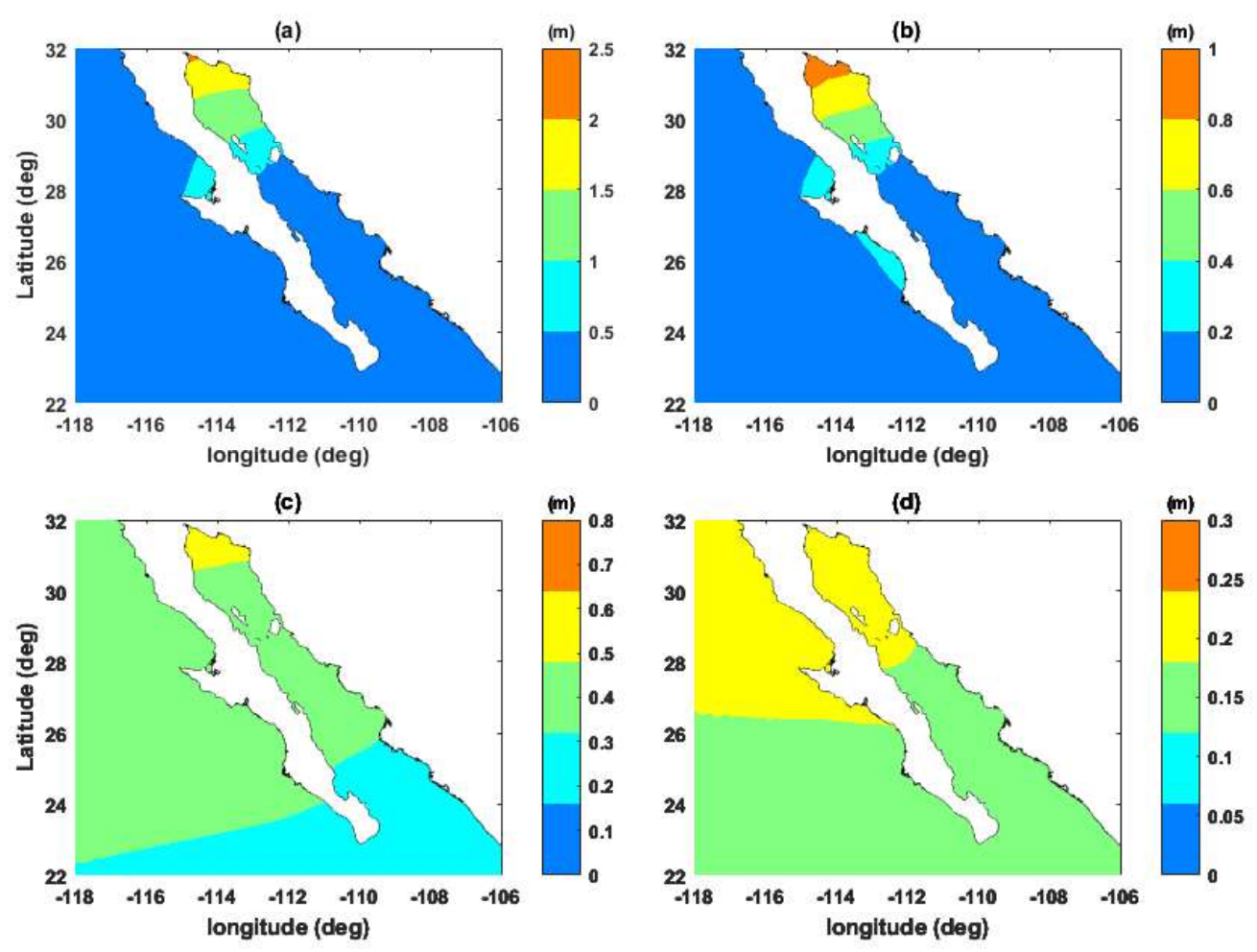

109 Fig. 1. Amplitude of the main semidiurnal and diurnal tidal constituents: (a) $\mathrm{M}_{2}$, (b) $\mathrm{S}_{2}$, (c) $\mathrm{K}_{1}$ and (d) $\mathrm{O}_{1}$, estimated by the TELEMAC model described in Section 2.

\section{2. Gulf of California model configuration and validation}

114 The GC hosts several deep basins, such as Tiburon, Delfin and Wagner, which are 400, 800 and $200 \mathrm{~m}$ deep,

115 respectively. The Midriff region contains some important Islands, such as Smith, Salsipuedes, San Lorenzo, and

116 San Esteban Islands. The biggest of the Gulf islands are Angel de la Guarda and Tiburon. The areas of most

117 interest to this study is the region around the Midriff Islands in the central region, as a previous study indicates

118 that currents in this region exceed $1.5 \mathrm{~m} / \mathrm{s}$ [9] and hence, as first shown by [8], there is good potential for tidal-

119 stream energy exploitation here, albeit in relatively deep ( $>200 \mathrm{~m})$ water - hence likely floating turbine technology

120 would be required for energy conversion.

121 A depth-averaged barotropic model of the GC was previously configured by [8] using the TELEMAC modelling suite [16]. Here we briefly describe the configuration and validation of that model. The TELEMAC modelling suite was chosen because of its: (1) computing performance - parallel processing, using the University of

124 Southampton's supercomputer, IRIDIS, optimizing the simulation time; (2) the finite element method enabled variable mesh resolution to focus modelling effort in areas of interest; and (3) model inputs and outputs are compatible with a number of pre and post-processing software (e.g. Blue Kenue, Fudaa, MATISSE, Janet). TELEMAC has been recently utilised in previous energy resource assessments, for different regions, e.g. [17, 18 and 19]. The open ocean boundaries conditions were driven utilising only tidal levels (not velocities) predicted from the TPXO 7.2 dataset (see Reference [8] for further details). The computed tidal harmonics from the numerical simulation are then explored to examine the impact of their application to theoretical tidal resource 
131 assessment within the annual yield estimate. The model mesh was built utilising the Blue Kenue software

132 developed by the National Research Council Canada (Fig. 2). The resolution of the mesh is $\sim 60 \mathrm{~km}$ in the open

133 ocean and along the Pacific Ocean coast, subsequently increases to $\sim 5 \mathrm{~km}$ at the entrance to the GC and to $\sim 1 \mathrm{~km}$

134 in the area of interest, around the Midriff Islands. It reduces to $\sim 3 \mathrm{~km}$ resolution in the northern most reaches of

135 the GC.

136 The model was extensively validated against tide gauge and ADCP (acoustic Doppler current profiler)

137 measurements to ensure the accuracy of the predicted hydrodynamic conditions in the GC. Locations of the ADCP

138 data are shown in Table 1. Data for 11 tide gauge stations (see [8] for more details) located in the GC region and

139 along the Mexican Pacific ocean coastline were obtained from CICESE, along with current velocity data from 4

140 ADCP moorings. A variety of methods were utilised to assess the reliability of the model performance in

141 accurately reproducing observed tidal levels and tidal currents. Therefore, modelled and observed tidal level and

142 currents were compared, along with the amplitude and phase for the main tidal constituents $\left(M_{2}, S_{2}, N_{2}, K_{1}, O_{1}\right.$,

$143 \mathrm{P}_{1}, \mathrm{Q}_{1}$ ), calculated using the T_TIDE MATLAB software package [20]. Additionally, percentage errors were

144 calculated to quantify the model's ability to reproduce the hydrodynamic conditions (see [8] for all the metrics of

145 the model validation).

146 In this paper we focus on carrying out two main sensitivity tests focusing on different bathymetries and choice of

147 tidal constituents. However, when setting up the model originally, we also undertook numerous sensitivity tests

148 to assess model perform for a range of different domain areas, mesh resolutions and using different uniform and

149 spatially varying bottom friction coefficients. The grid resolution was gradually increased, to quantify if validation

150 against observations improved with higher resolution. With higher resolution model run times increase

151 significantly, so there is a balance between capturing approach resolutions and ensuring the simulations can be

152 made in appropriate time-scales. Numerous sensitivity tests were undertaken to assess model perform using a

153 range of uniform and spatially varying bottom friction coefficients and the different friction law options that are

154 available in TELEMAC (e.g., Nikuradse, Manning and Chézy formula). Overall, differences between the model

155 predictions and measurements were lowest when the Manning's law was used to define friction and when a

156 spatially uniform value of $0.030\left(\mathrm{~s} / \mathrm{m}^{1 / 3}\right)$ was used. In addition, the accuracy of the model predictions were

157 sensitive to the resolution and quality of the bathymetry data interpolated onto the model grid (see Appendix B

158 which includes the steering file for the model settings in TELEMAC 2D [21]). 
(a)

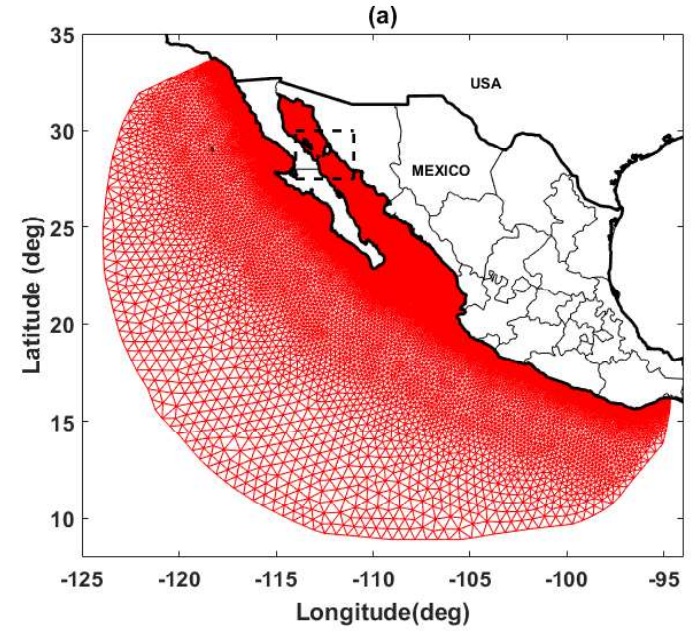

159

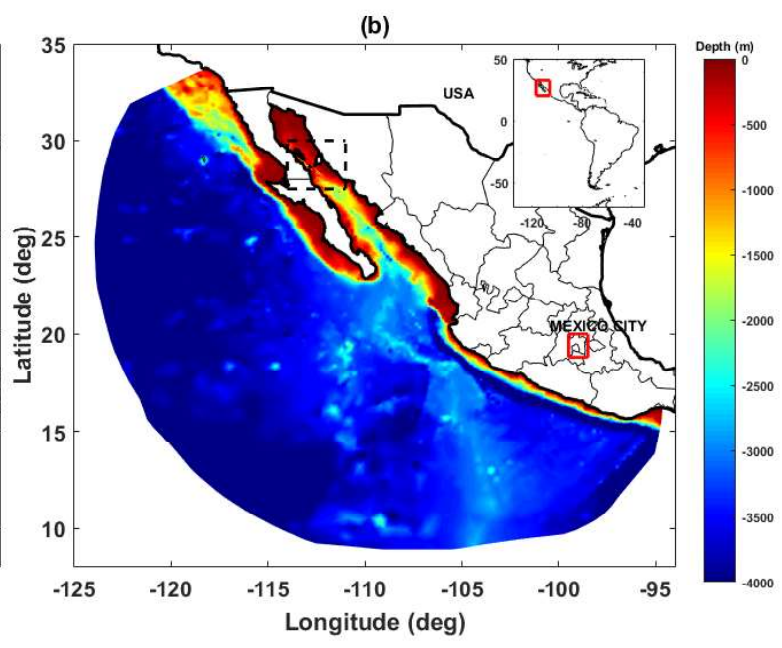

(d)

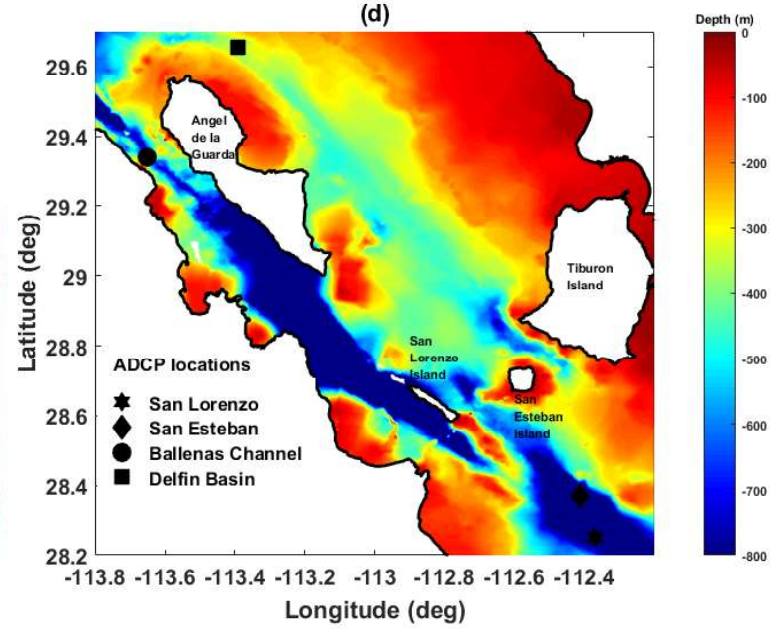

(b)
160

161

162

163

164

165

166

167

168 (c)

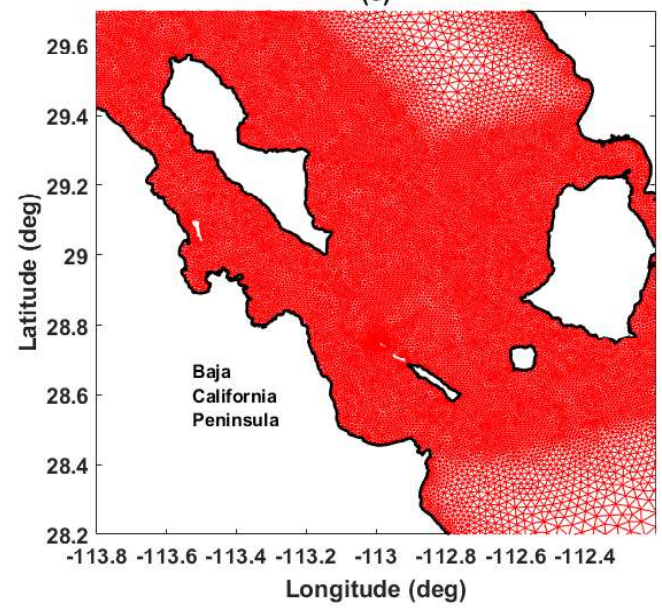


176 (north of $27^{\circ}$ to $32^{\circ}$ ) GC. The extent of the bathymetry dataset is shown in Fig. 3 for the GC, and the Midriff

177 region of the GC and the northern GC. The higher resolution bathymetry dataset was combined with GEBCO

178 using a merge function in ArcGIS software which combined multiple inputs of datasets even though the data

179 overlap. Consequently, none of the points from either the GEBCO_2014 or CICESE data sets were omitted or

180 altered. A cross-sectional from the central region of the GC is shown in Fig. 4, highlighting the main differences

181 for the three different products utilized in this work. The three different model bathymetries within the Midriff

182 region are shown in Fig. 5, and can be seen to vary between the main islands in this area.

183 Second, we examined how current speeds, mean kinetic power density and annual mean power estimates varied

184 depending on which tidal constituents were used to predict tidal levels. The open ocean boundaries were driven

185 using tidal levels predicted from the TPXO 7.2 dataset [22 and 23]. The ocean model was always forced by the

186 eight main diurnal and semi-diurnal constituents $\left(\mathrm{M}_{2}, \mathrm{~S}_{2}, \mathrm{~N}_{2}, \mathrm{~K}_{1}, \mathrm{O}_{1}, \mathrm{P}_{1}, \mathrm{Q}_{1}\right)$, three nonlinear constituents ( $\mathrm{M}_{4}$,

$187 \mathrm{MS}_{4}, \mathrm{MN}_{4}$ ), and two long period constituents (Mf, Mm), at $1 / 4^{\circ}$ resolution. Our high-resolution grid simulates the

188 interaction among constituents, thus resolving higher harmonics (e.g., $\mathrm{M}_{4}, \mathrm{M}_{6}$ and $\mathrm{M}_{8}$ ). We ran the model for a 1-

189 month period and carried out a harmonic analysis on the predicted tidal levels, using T_TIDE in MATLAB. To

190 avoid computational constraints, we then used the tidal current harmonics to predict the tidal currents for a full

191 year. First, we estimated the peak current speeds, mean kinetic power density and annual mean power, considered

192 all the 29 tidal constituents returned by the T_TIDE harmonic analysis [8]. Then, the peak current speeds, KPD

193 and the annual maximum theoretical undisturbed mean power, were calculated considering: (1) only the $\mathrm{M}_{2}$ tidal

194 constituent; (2) only the $\mathrm{S}_{2}$ constituent, and the finally (3) the $\mathrm{M}_{2}$ plus $\mathrm{S}_{2}$ constituent. 


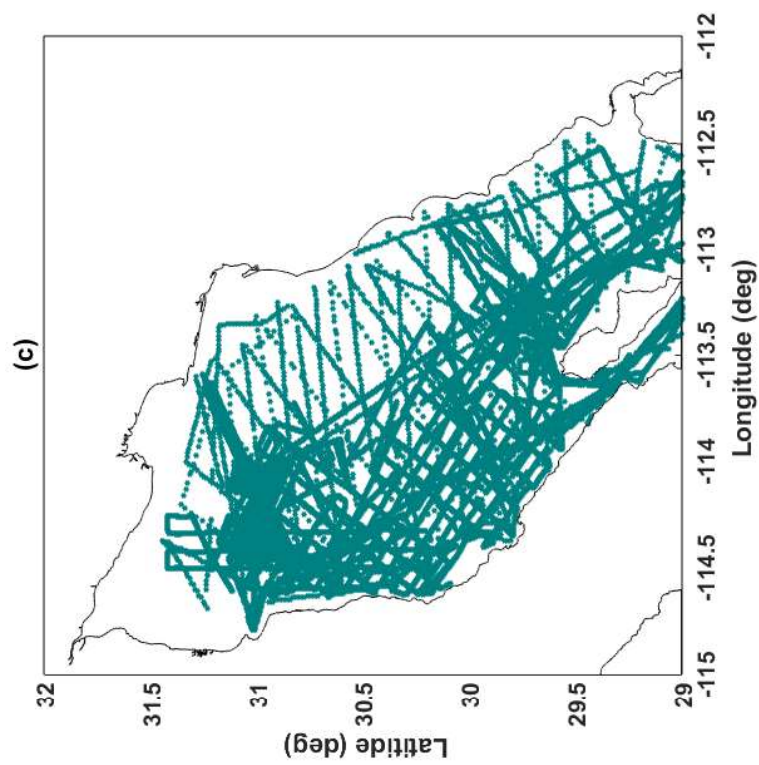

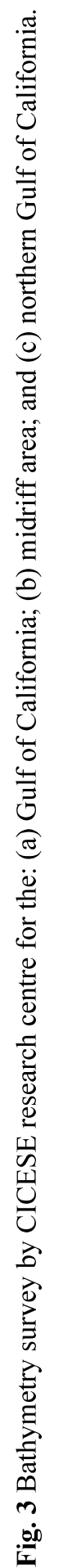

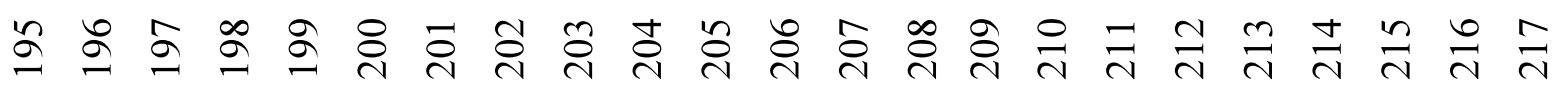



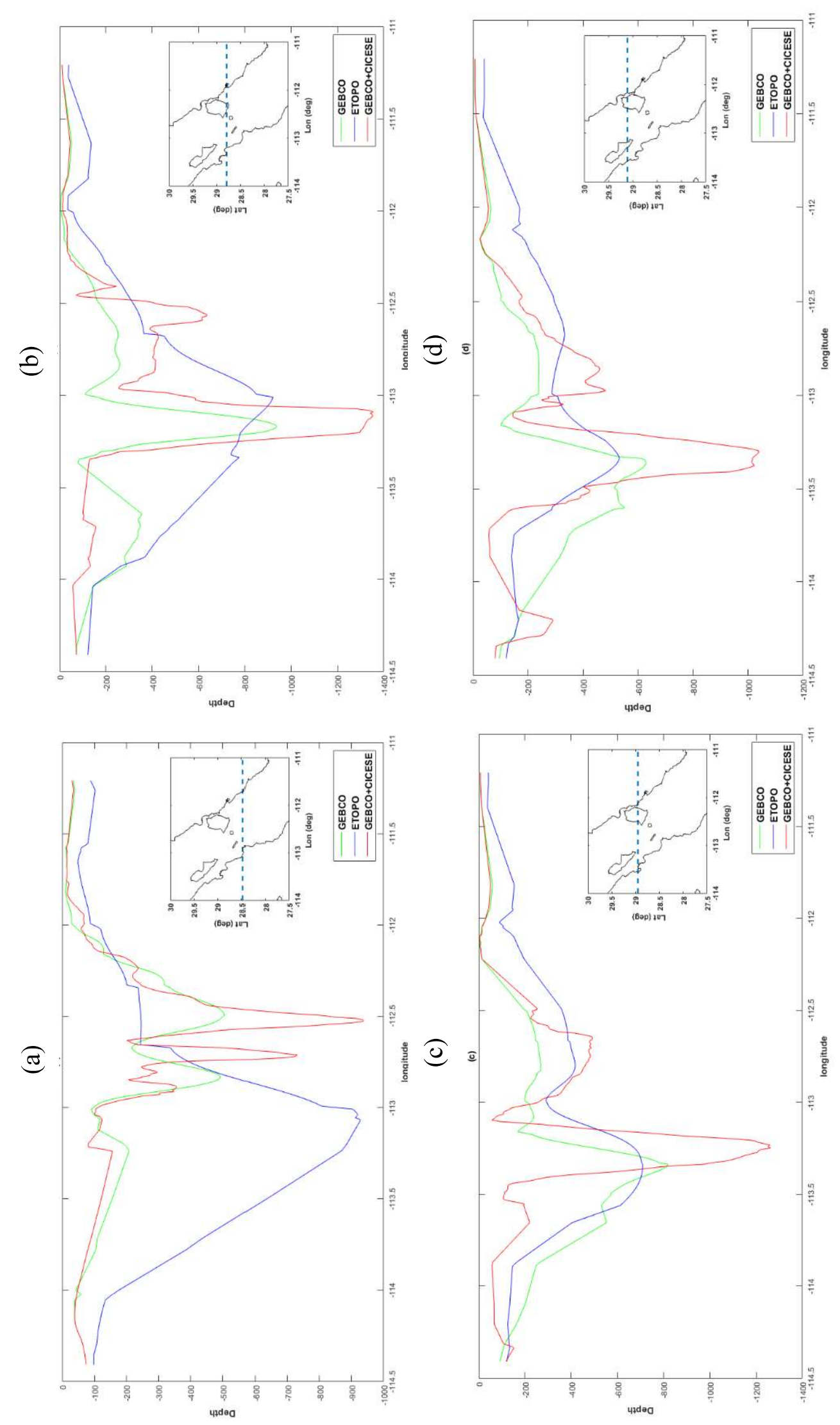


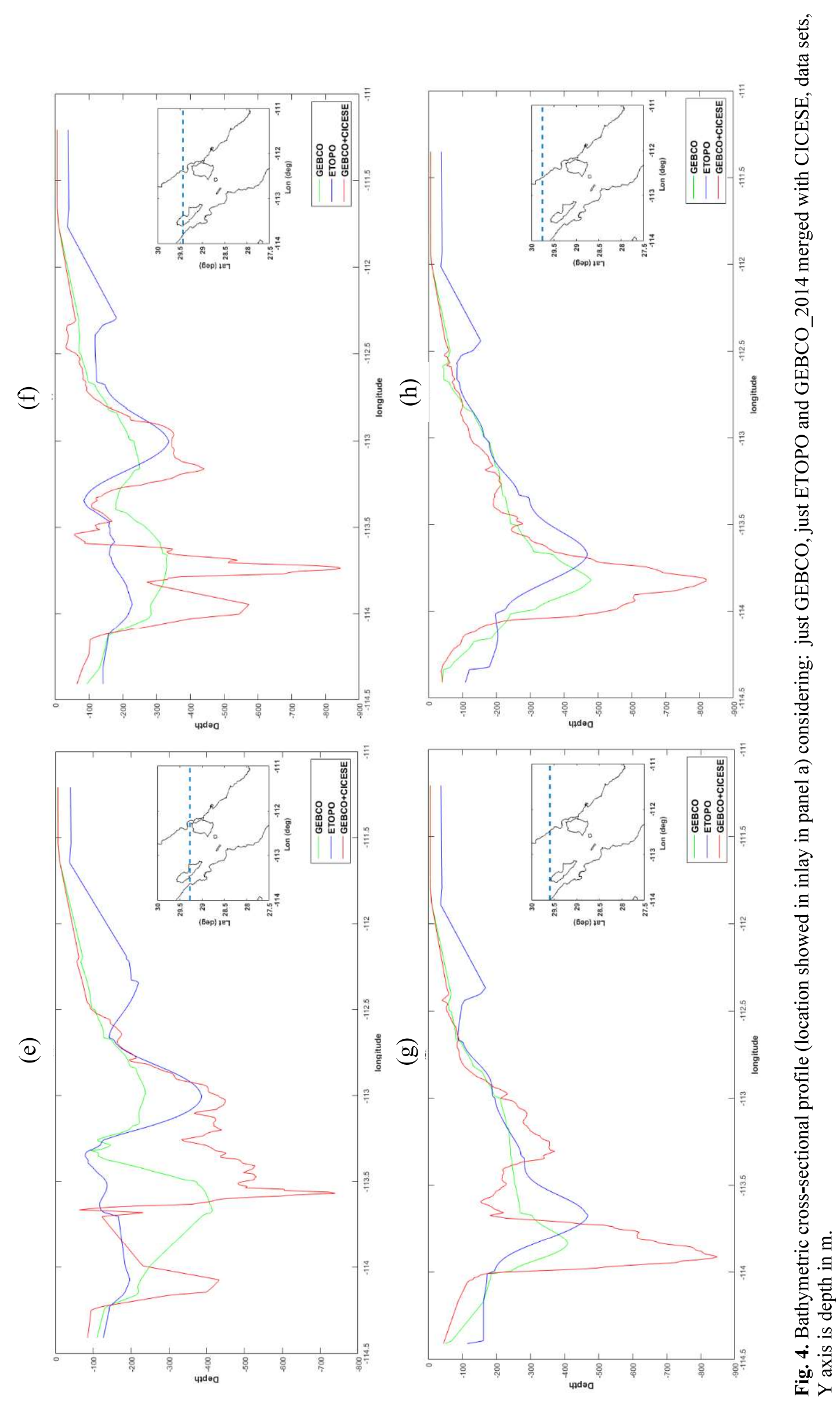




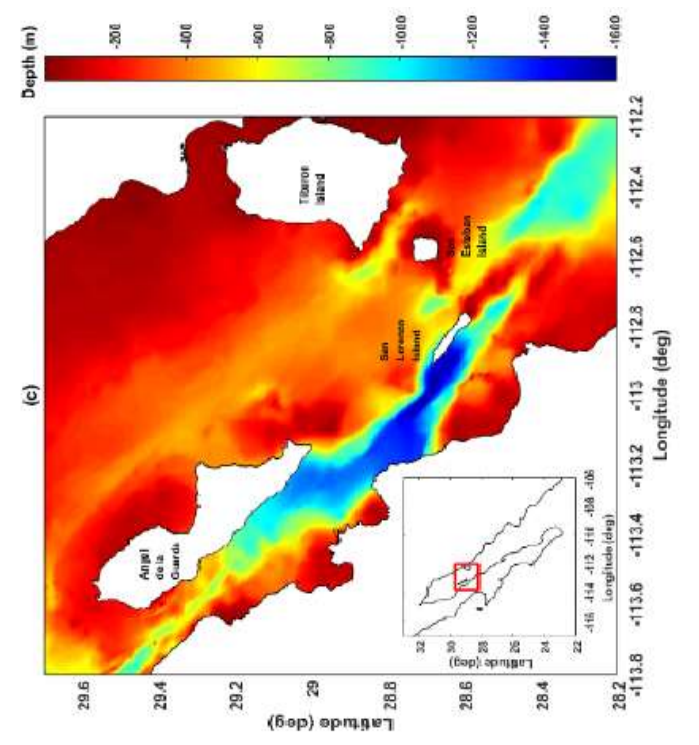

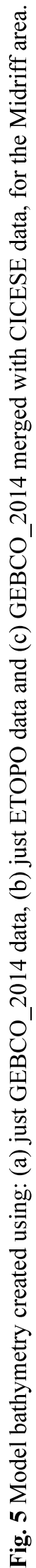

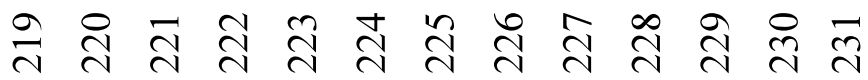




\section{Results}

233 The results are presented in three sub-sections below. The first sub-section discusses the model validation,

234 obtained using the three different bathymetries. The second and third sub-sections describe the results of the 235 bathymetry and tidal constituent sensitivity tests, respectively.

\section{$237 \quad 4.1$ Model validation}

238 This section presents the GC model validation and how the validation varies across the three different bathymetry 239 products (Fig. 6) Model validation is important as it gives confidence in the model's ability to reproduce the tidal 240 flows in the region with reasonable accuracy. Percentage errors and RMSE were used to quantify the validation 241 for the three different bathymetry products utilized within the model simulations, at the 11 tide gauge stations (see 242 [8] for the tide gauge locations), and are listed in Table 2 and Table 3, respectively. The largest percentage error 243 is at $\mathrm{La} \mathrm{Paz}(11.5 \%)$ using the ETOPO bathymetry product, while the smallest errors are at Ensenada (1.1\%, 1.2 $244 \%$ and $1.2 \%$ ) using the three different products respectively (GEBCO, ETOPO, and GEBCO merged with 245 CICESE). The mean percentage error across all sites is $5 \%$ using the combined bathymetry data. The percentage 246 errors are largest at Guerrero Negro (9.6\%, where the tide gauge is in an enclosed bay), Cabo San Lucas (3\%), 247 Manzanillo (6.1\%) and Acapulco (7.7\%). However, the mean percentage error overall for GEBCO_2014 and 248 CICESE merged bathymetry product was slightly better at around 4 to $6 \%$. Therefore, the model provides better 249 representation of tidal levels across all the domain region using the combined GEBCO_2014 and CICESE 250 datasets.

251 A comparison between eastward $(u)$ and northward $(v)$ velocity components for the 4 ADCP locations utilising 252 the three bathymetry products are shown in Fig. 7 and 8 respectively. Graphically, significant differences can be 253 seen when using just the GEBCO_2014 and ETOPO products. For $\mathrm{u}$ and $\mathrm{v}$ current components, smaller predicted 254 current speeds were found at San Lorenzo (Fig. 7a and 8a) and San Esteban Island (Fig. 7b and 8b) while closer 255 approximations of the current speeds were predicted at Ballenas channel (Fig. 6g and 7g) and Delfin Basin (Fig. $2567 \mathrm{j}$ and $8 \mathrm{j}$ ) using GEBCO_2014 only. In contrast, both velocity components were overestimated while using 257 ETOPO bathymetry data only within Ballenas channel (Fig. 7h and 8h) and Delfin basin (Fig. 7k and 8k). 
Table 1 ADCP location and deployment details

\begin{tabular}{cccc}
\hline Site Name & $\begin{array}{c}\text { Depth device deployment/ } \\
\text { water depth in } \mathbf{~ m}\end{array}$ & Longitude (decimal $^{\circ}$ ) & Latitude (decimal $^{\circ}$ ) \\
\hline San Lorenzo & $395 / 410$ & -112.37 & 28.25 \\
San Esteban & $577 / 588$ & -112.41 & 28.37 \\
Ballenas & $578 / 595$ & -113.38 & 29.20 \\
Channel & & & \\
Delfin & $337 / 354$ & -113.23 & 29.38 \\
\hline
\end{tabular}

267

268

269 Table 2 Statistic percentage errors calculated of tidal level constituents for the 11 tide gauges stations using 270 different bathymetry products.

\begin{tabular}{|c|c|c|c|c|}
\hline $\begin{array}{c}\text { Site } \\
\text { number }\end{array}$ & Site Name & $\begin{array}{l}\text { \% Error } \\
\text { GEBCO }\end{array}$ & $\begin{array}{l}\text { \% Error } \\
\text { ETOPO }\end{array}$ & $\begin{array}{c}\% \text { Error } \\
\text { GEBCO merged with } \\
\text { CICESE }\end{array}$ \\
\hline 1 & Ensenada & 1.1 & 1.2 & 1.2 \\
\hline 2 & San Quintin & 4.4 & 4.8 & 4.5 \\
\hline 3 & Isla Cedros & 4.3 & 4.5 & 4.4 \\
\hline 4 & $\begin{array}{l}\text { Guerrero } \\
\text { Negro }\end{array}$ & 9.4 & 8.9 & 9.6 \\
\hline 5 & $\begin{array}{l}\text { Cabo San } \\
\text { Lucas }\end{array}$ & 2.10 & 2.7 & 3.0 \\
\hline 6 & $\mathrm{La} \mathrm{Paz}$ & 11.2 & 11.5 & 10.9 \\
\hline 7 & Loreto & 6.3 & 4.5 & 5.9 \\
\hline 8 & $\begin{array}{l}\text { Bahia de los } \\
\text { Angeles }\end{array}$ & 7 & 6.8 & 3.0 \\
\hline 9 & San Felipe & 5.1 & 3.3 & 3.8 \\
\hline 10 & Manzanillo & 6 & 6 & 6.1 \\
\hline 11 & Acapulco & 7.4 & 7.4 & 7.7 \\
\hline All & Mean & 5.4 & 5.6 & 5.0 \\
\hline
\end{tabular}


273 Table 3 RMSE calculated of tidal level constituents for the 11 tide gauges stations using different bathymetry 274 products.

\begin{tabular}{|c|c|c|c|c|}
\hline $\begin{array}{c}\text { Site } \\
\text { number }\end{array}$ & Site Name & $\begin{array}{c}\text { RMSE } \\
\text { GEBCO }\end{array}$ & $\begin{array}{c}\text { RMSE } \\
\text { ETOPO }\end{array}$ & $\begin{array}{c}\text { RMSE } \\
\text { GEBCO merged with } \\
\text { CICESE }\end{array}$ \\
\hline 1 & Ensenada & 0.03 & 0.03 & 0.03 \\
\hline 2 & San Quintin & 0.11 & 0.11 & 0.11 \\
\hline 3 & Isla Cedros & 0.1 & 0.1 & 0.1 \\
\hline 4 & $\begin{array}{l}\text { Guerrero } \\
\text { Negro }\end{array}$ & 0.25 & 0.24 & 0.26 \\
\hline 5 & $\begin{array}{l}\text { Cabo San } \\
\text { Lucas }\end{array}$ & 0.04 & 0.04 & 0.06 \\
\hline 6 & $\mathrm{La} \mathrm{Paz}$ & 0.19 & 0.18 & 0.19 \\
\hline 7 & Loreto & 0.08 & 0.06 & 0.08 \\
\hline 8 & $\begin{array}{l}\text { Bahia de los } \\
\text { Angeles }\end{array}$ & 0.22 & 0.22 & 0.09 \\
\hline 9 & San Felipe & 0.33 & 0.21 & 0.25 \\
\hline 10 & Manzanillo & 0.07 & 0.07 & 0.07 \\
\hline 11 & Acapulco & 0.07 & 0.07 & 0.07 \\
\hline All & Mean & 0.13 & 0.12 & 0.11 \\
\hline
\end{tabular}



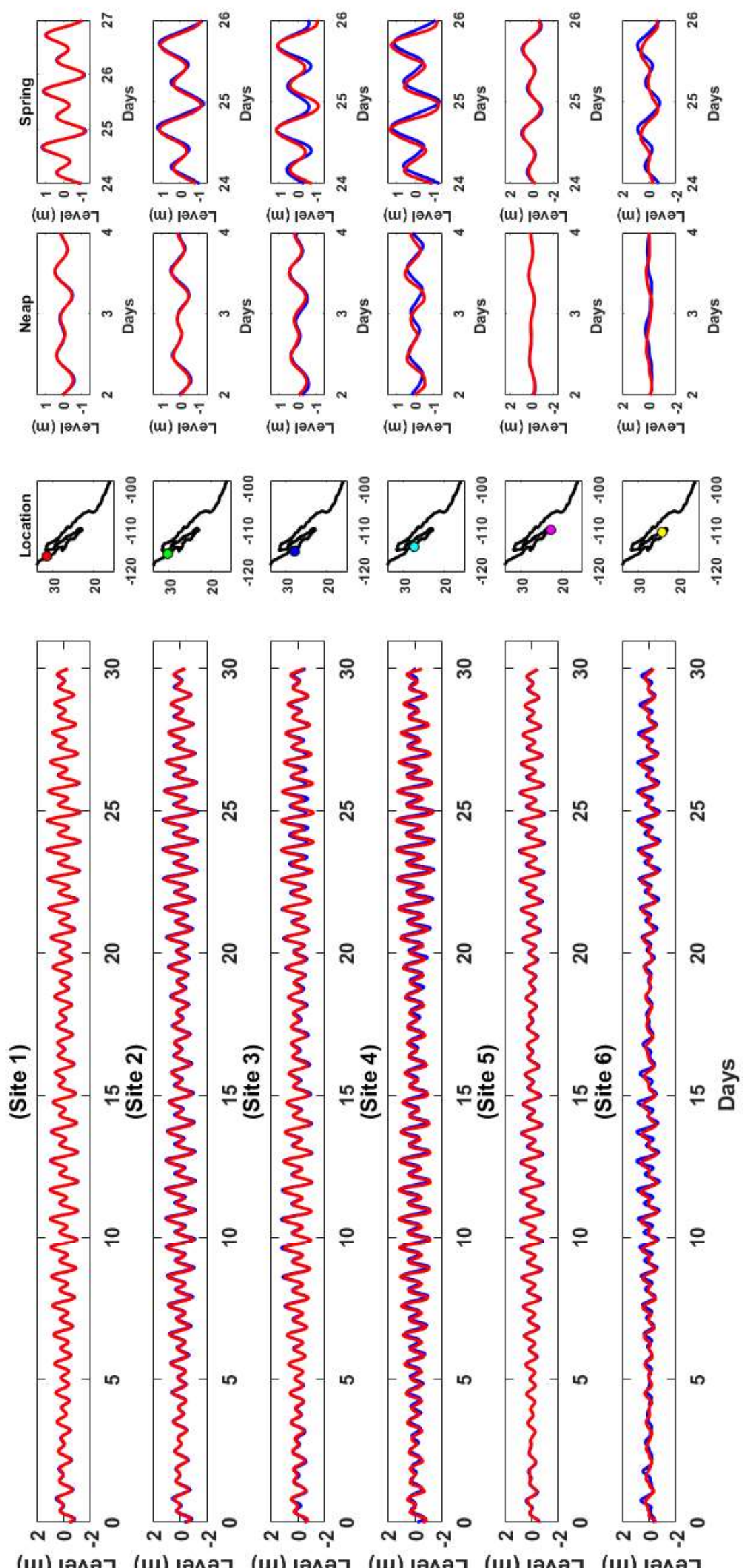

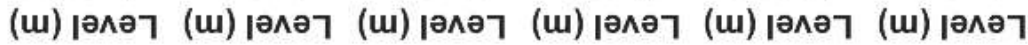

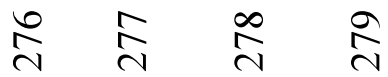




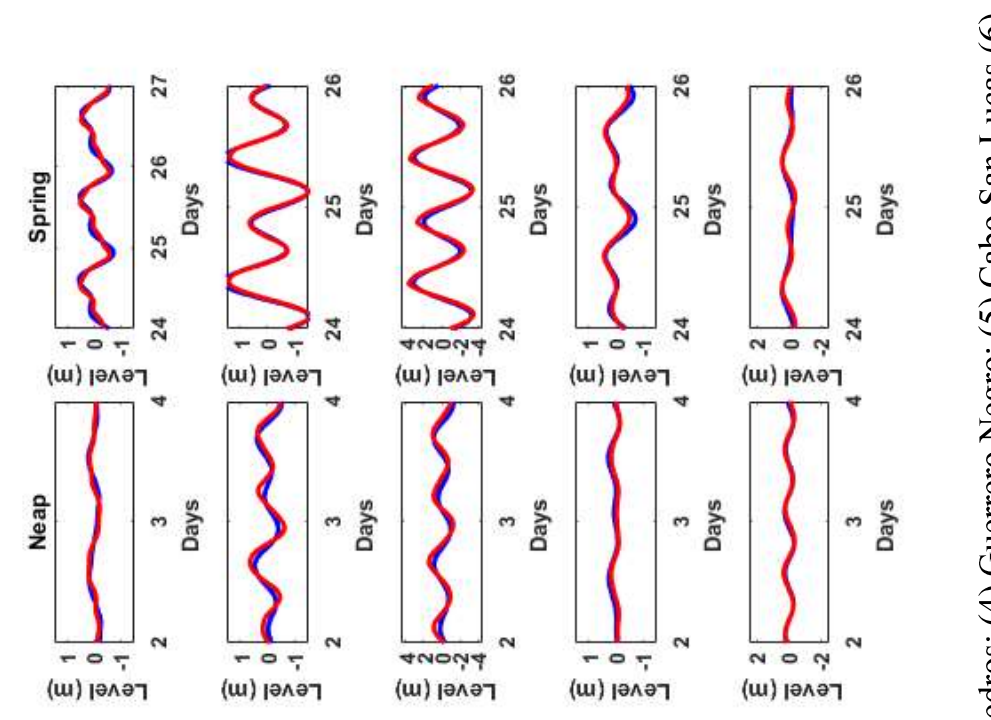

6)
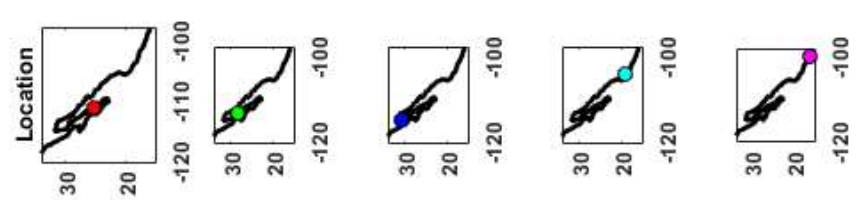

ปั ญี

3

สี

造

ลำ

을

造

원은

डิ

(于.

के

항

它

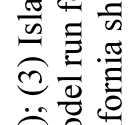

毛丰

要焉

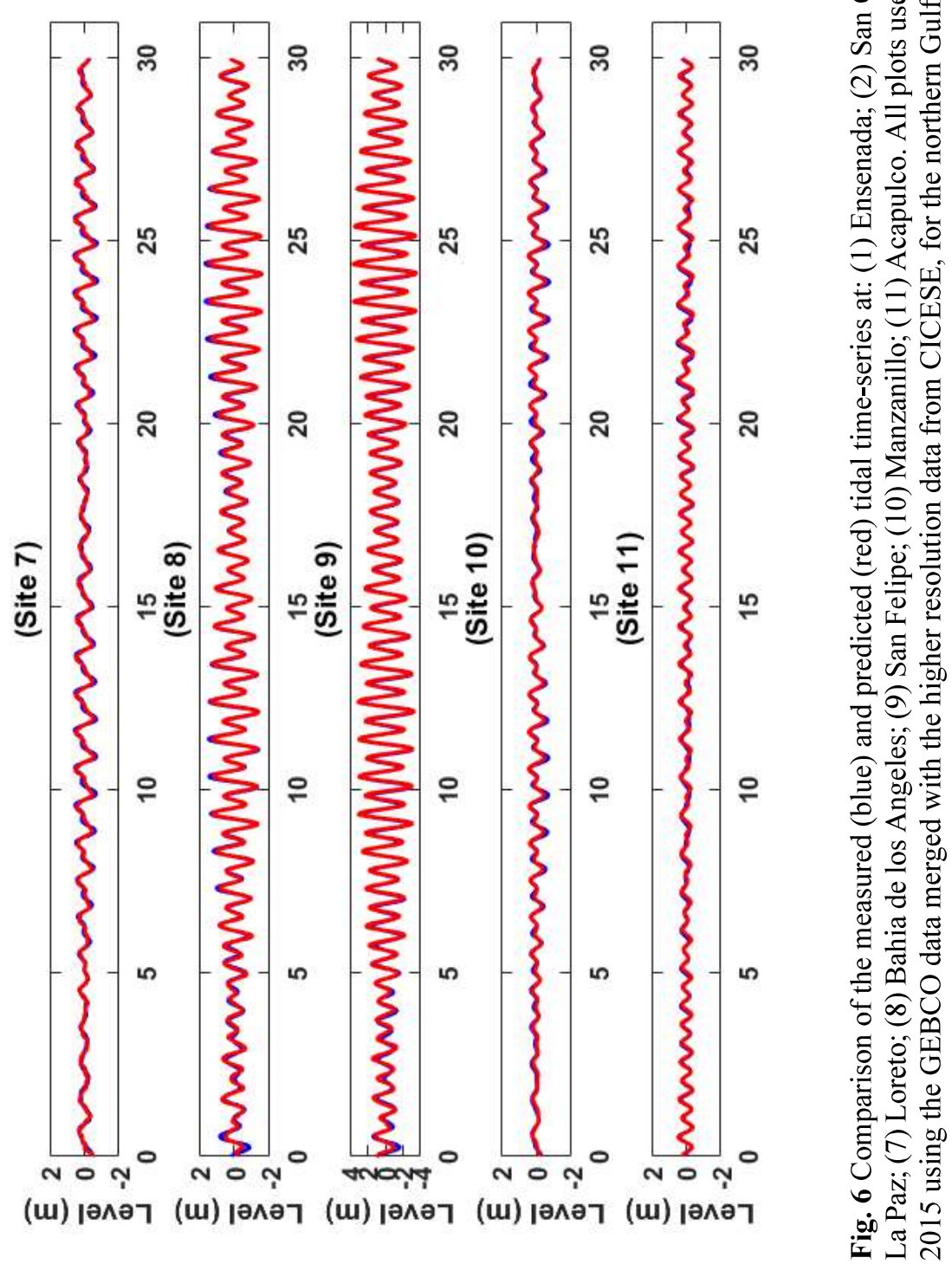

劳

조을

चั

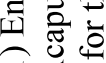

远约

\%

范

曹 $\frac{\pi}{0} \frac{\pi}{0}$

宂氖.

过

离离

go

(2)

링

这

檼

可

क्

오ㅇㅝㅝ

흥

층.

분

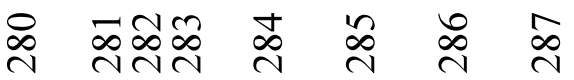




$$
111
$$




$$
11
$$


298 Percentage errors and RMSE were calculated to quantify the model skill, for each of the three bathymetries, at the

2994 ADCP locations and these are listed in Table 4 and Table 5 (see Fig $2 \mathrm{~d}$ for the ADCP locations). The largest

300 error of the $\mathrm{v}$ component is in Ballenas channel using GEBCO (17.0\%) and ETOPO (26.1\%) bathymetric data

301 on their own. Ballenas channel is relatively deep at around 800 to $900 \mathrm{~m}$, and we assume that the bathymetry

302 products influence negatively the predicted $\mathrm{u}$ and $\mathrm{v}$ component. The smallest errors for the $\mathrm{u}$ and $\mathrm{v}$ components

303 are at Delfin basin; which are $2.7 \%$ and $3.7 \%$, respectively, when using the combined GEBCO and CICESE

304 data. Therefore, we can conclude that a higher resolution bathymetry data can contribute significantly to improve

305 the current validation. In summary, the model validation improved when the higher resolution bathymetry data

306 for the Midriff region (obtained from CICESE with a resolution of $450 \mathrm{~m}$ ) was merged within the GEBCO dataset

307 ( $\sim 900$ m resolution) (Fig. 6e,f) compared to just using GEBCO (Fig. 7a,b) or ETOPO data alone (Fig. 8 c,d). In

308 addition, the absolute current velocity comparisons are shown in Table 6. Furthermore, amplitude and phases of

309 the $\mathrm{u}$ and $\mathrm{v}$ velocity components utilising $\mathrm{M}_{2}$ and $\mathrm{S}_{2}$ model simulation are shown in table 7 and 8 respectively.

310 Amplitude and phases results were estimated using the merged bathymetry data (GEBCO_2014 merged with

311 CICESE).

312 Table 4: Percentage error of $u$ and v velocity components using different bathymetry products

\begin{tabular}{|c|c|c|c|c|c|c|}
\hline Site Name & $\begin{array}{c}\text { \% Error } \\
\text { GEBCO } \\
\text { u }\end{array}$ & $\begin{array}{c}\% \text { Error } \\
\text { GEBCO } \\
\text { v }\end{array}$ & $\begin{array}{c}\text { \% Error } \\
\text { ETOPO } \\
\text { u }\end{array}$ & $\begin{array}{c}\text { \% Error } \\
\text { ETOPO } \\
\text { v }\end{array}$ & $\begin{array}{c}\text { \% Error } \\
\text { GEBCO } \\
\text { merged } \\
\text { with } \\
\text { CICESE u }\end{array}$ & $\begin{array}{c}\text { \% Error } \\
\text { GEBCO } \\
\text { merged } \\
\text { with } \\
\text { CICESE v }\end{array}$ \\
\hline $\begin{array}{c}\text { San } \\
\text { Lorenzo }\end{array}$ & 13.81 & 11.38 & 11.82 & 5.89 & 11.3 & 8.5 \\
\hline $\begin{array}{c}\text { San } \\
\text { Esteban }\end{array}$ & 14.77 & 9.20 & 12.55 & 4.31 & 11.5 & 6.7 \\
\hline $\begin{array}{l}\text { Ballenas } \\
\text { Channel }\end{array}$ & 3.25 & 16.97 & 15.28 & 26.12 & 6.7 & 25.0 \\
\hline Delfin & 8.50 & 5.99 & 2.92 & 3.28 & 2.7 & 3.7 \\
\hline Mean & 10.08 & 10.88 & 10.64 & 9.90 & 8.04 & 11 \\
\hline
\end{tabular}


319 Table 5: RMSE error of $\mathrm{u}$ and v velocity components using different bathymetry products

\begin{tabular}{|c|c|c|c|c|c|c|}
\hline Site Name & $\begin{array}{c}\text { RMSE } \\
\text { GEBCO } \\
\text { u }\end{array}$ & $\begin{array}{c}\text { RMSE } \\
\text { GEBCO } \\
\text { v }\end{array}$ & $\begin{array}{c}\text { RMSE } \\
\text { ETOPO } \\
\text { u }\end{array}$ & $\begin{array}{c}\text { RMSE } \\
\text { ETOPO } \\
\text { v }\end{array}$ & $\begin{array}{c}\text { RMSE } \\
\text { GEBCO } \\
\text { merged } \\
\text { with } \\
\text { CICESE } \\
\text { u }\end{array}$ & $\begin{array}{c}\text { RMSE } \\
\text { GEBCO } \\
\text { merged } \\
\text { with } \\
\text { CICESE v }\end{array}$ \\
\hline $\begin{array}{c}\text { San } \\
\text { Lorenzo }\end{array}$ & 0.18 & 0.14 & 0.16 & 0.07 & 0.18 & 0.12 \\
\hline $\begin{array}{c}\text { San } \\
\text { Esteban }\end{array}$ & 0.21 & 0.11 & 0.18 & 0.05 & 0.19 & 0.10 \\
\hline $\begin{array}{l}\text { Ballenas } \\
\text { Channel }\end{array}$ & 0.03 & 0.29 & 0.16 & 0.45 & 0.09 & 0.32 \\
\hline Delfin & 0.05 & 0.03 & 0.02 & 0.02 & 0.02 & 0.03 \\
\hline Mean & 0.12 & 0.15 & 0.13 & 0.15 & 0.12 & 0.14 \\
\hline
\end{tabular}

321 Table 6: Comparison of the measured and predicted absolute current velocity in $(\mathrm{m} / \mathrm{s})$ for the bathymetry 322 products used on this study.

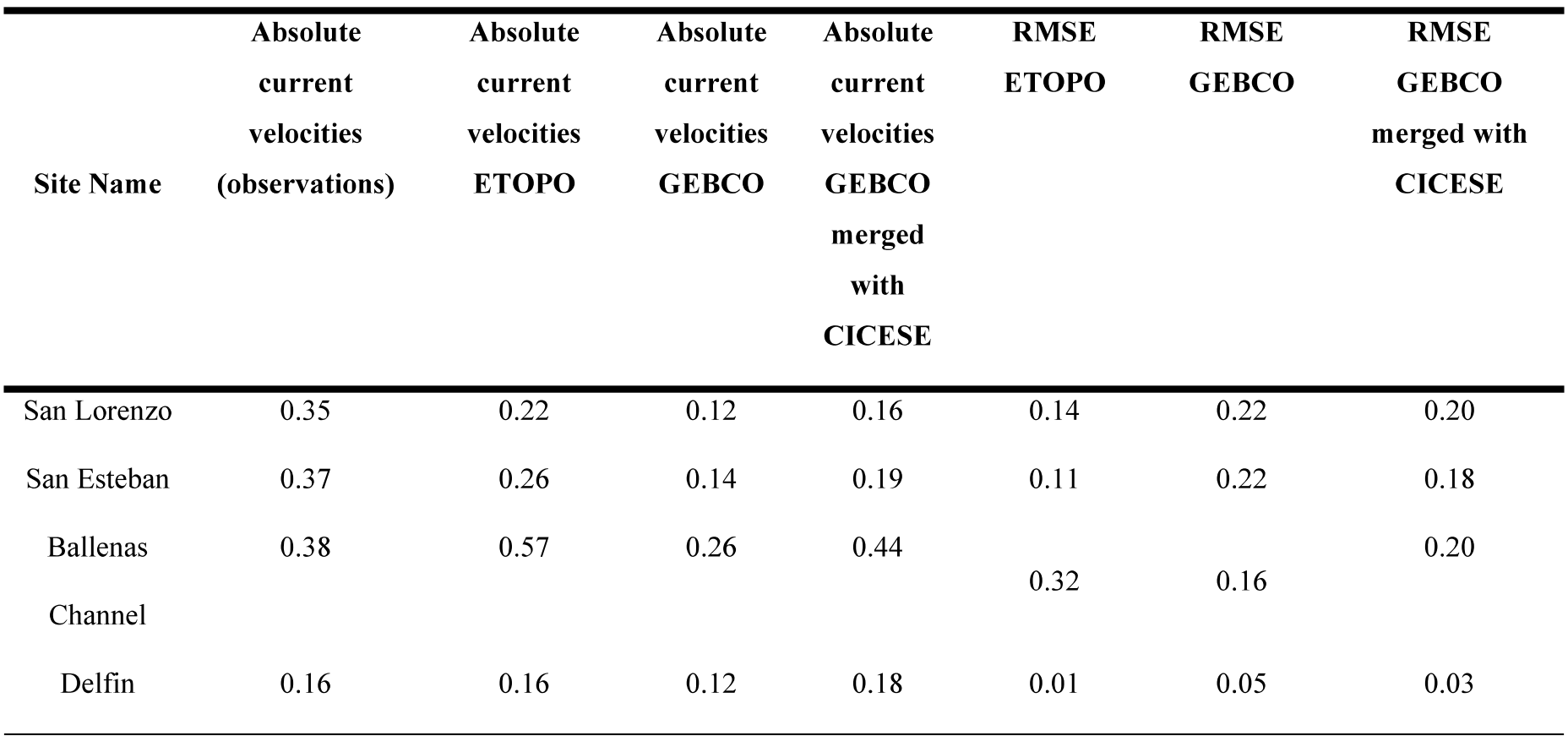


Table 7: Comparison of the measured and predicted $u$ and $v$ velocity amplitudes and phases at the four ADCP 326 sites for $\mathrm{M}_{2}$ tidal constituent.

\begin{tabular}{|c|c|c|c|c|c|c|c|c|c|c|}
\hline \multirow{2}{*}{ Site Name } & \multicolumn{3}{|c|}{$\begin{array}{l}\text { Amplitude } \\
\text { model (m) }\end{array}$} & \multicolumn{2}{|c|}{$\begin{array}{l}\text { Amplitude } \\
\text { Observations (m) }\end{array}$} & $\mathbf{M}_{2}$ & \multicolumn{2}{|c|}{$\begin{array}{l}\text { Phase } \\
\text { model }\left({ }^{\circ}\right)\end{array}$} & \multicolumn{2}{|c|}{$\begin{array}{l}\text { Phase } \\
\text { Observations }\left(^{\circ}\right)\end{array}$} \\
\hline & $\overline{\mathrm{u}}$ & $\mathrm{v}$ & & $\mathrm{u}$ & $\mathrm{v}$ & & $\mathrm{u}$ & $\mathrm{v}$ & $\mathrm{u}$ & $\mathrm{v}$ \\
\hline San Lorenzo & 0.009 & 0.013 & & 0.030 & 0.003 & & 210 & 139 & 178 & 186 \\
\hline San Esteban & 0.010 & 0.015 & & 0.039 & 0.003 & & 220 & 139 & 222 & 169 \\
\hline $\begin{array}{l}\text { Ballenas } \\
\text { Channel }\end{array}$ & 0.029 & 0.031 & & 0.023 & 0.005 & & 221 & 141 & 229 & 181 \\
\hline Delfin & 0.014 & 0.011 & & 0.013 & 0.001 & & 215 & 121 & 210 & 207 \\
\hline
\end{tabular}

327

328

329

330

Table 8: Comparison of the measured and predicted $u$ and $v$ velocity amplitudes and phases at the four ADCP sites for $\mathrm{S}_{2}$ tidal constituent.

\begin{tabular}{|c|c|c|c|c|c|c|c|c|}
\hline \multirow{2}{*}{ Site Name } & \multicolumn{2}{|c|}{$\begin{array}{c}\text { Amplitude } S_{2} \\
\operatorname{model}(m)\end{array}$} & \multicolumn{2}{|c|}{$\begin{array}{c}\text { Amplitude } S_{2} \\
\text { Observations (m) }\end{array}$} & \multicolumn{2}{|c|}{$\begin{array}{c}\text { Phase } \mathbf{S}_{\mathbf{2}} \text { model } \\
\left(^{\circ}\right)\end{array}$} & \multicolumn{2}{|c|}{$\begin{array}{c}\text { Phase } S_{2} \\
\text { Observations }\left(^{\circ}\right)\end{array}$} \\
\hline & $\mathrm{u}$ & $\mathrm{V}$ & $\mathrm{u}$ & $\mathrm{v}$ & $\mathrm{u}$ & $\mathrm{v}$ & $\mathrm{u}$ & $\mathrm{v}$ \\
\hline San Lorenzo & 0.0091 & 0.0132 & 0.0303 & 0.0033 & 210 & 139 & 178 & 186 \\
\hline San Esteban & 0.0104 & 0.0156 & 0.0393 & 0.0036 & 220 & 139 & 222 & 169 \\
\hline $\begin{array}{l}\text { Ballenas } \\
\text { Channel }\end{array}$ & 0.0297 & 0.0316 & 0.0239 & 0.0056 & 221 & 141 & 229 & 181 \\
\hline Delfin & 0.0146 & 0.0115 & 0.0134 & 0.0011 & 215 & 121 & 210 & 207 \\
\hline
\end{tabular}

331

332 There are a few cases, at particular sites, when the GEBCO_2014 merged with CICESE bathymetry does not give 333 the lowest root mean square error (RMSE) difference listed in Tables 3, 4, 5 and 6. However, when the RMSEs 334 are averaged across all the 11 tide gauge sites, or all 4 current sites, then the GEBCO_2014 merged with CICESE 335 bathymetry consistently gives the best overall agreement between the observed and measured time-series. The 336 averaged RMSE errors are listed in the last row of Tables 3, 4, 5 and 6 . In all cases it can be seen that the 337 GEBCO_2014 merged with CICESE bathymetry consistently gives the best agreement. 


\section{$340 \quad 4.2$ Bathymetry sensitivity tests}

341 Next, we compare the maximum current speeds and the estimated 'theoretical' power from the three different

342 bathymetry simulations, for the Midriff region (Fig. $4 \mathrm{c}$ and $5 \mathrm{c}$ ). Current speeds vary significantly between the 343 three different bathymetry products within the four main regions where current speeds exceed $1 \mathrm{~m} / \mathrm{s}$ (Fig. 9). The

344 largest current speeds were localised within San Lorenzo Passage (channel between San Lorenzo and San Esteban 345 Island) reaching a maximum of about $2.4 \mathrm{~m} / \mathrm{s}$ in the deeper-water $(\sim 500 \mathrm{~m})$ for the combined GEBCO and 346 CICESE bathymetry. In contrast, when using just GEBCO or ETOPO bathymetry products, the current speeds in 347 this channel reduce to around $1.2 \mathrm{~m} / \mathrm{s}$ and $0.8 \mathrm{~m} / \mathrm{s}$, respectively. Similarly, in the region of Ballenas channel 348 (channel between Angel de la Guarda Island and the Baja California Peninsula) relatively large differences were 349 found. Using the combined bathymetry dataset (Fig. 9c) the flow speed was estimated to be around $1 \mathrm{~m} / \mathrm{s}$, whereas 350 using GEBCO data only (Fig. 9a) the current speed reduced to $0.5 \mathrm{~m} / \mathrm{s}$. However, the use of ETOPO bathymetry 351 overestimated the current speed within Ballenas channel at around $1.8 \mathrm{~m} / \mathrm{s}$ (Fig. 9b). 


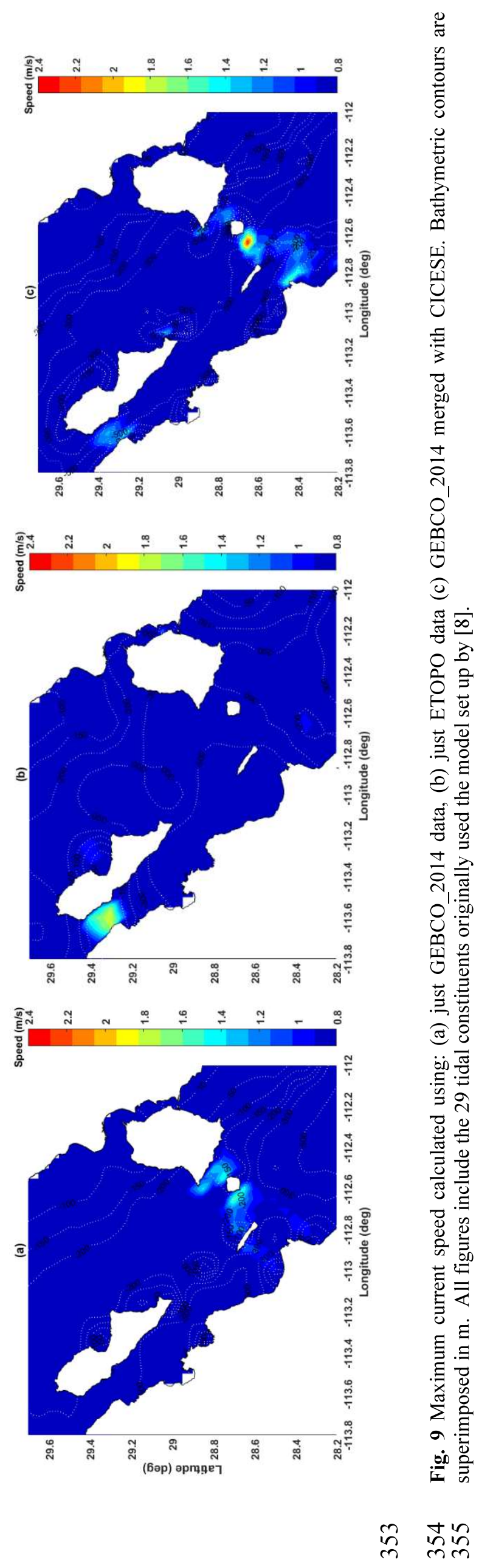


The annual mean power is significantly underestimated when using just the GEBCO_2014 or ETOPO bathymetry data sources on their own for the Midriff region (Fig. 10). For the region with fastest current speeds, San Lorenzo Passage, the annual mean power was $150 \mathrm{MW}$ and $20 \mathrm{MW}$ when using the GEBCO_2014 and ETOPO bathymetries, respectively (Fig. 10a and c. Whereas the annual mean power was calculated as $\sim 200 \mathrm{MW}$ when using the bespoke dataset (Fig. 10f). Similarly, in the region between San Lorenzo and the Baja California peninsula (Marker B on Fig. 5a) where the currents speeds are around $1.4 \mathrm{~m} / \mathrm{s}$, the annual mean power was estimated to be around $160 \mathrm{MW}$ when using the combined bathymetry products whereas the resource reduces approximately to $80 \mathrm{MW}$ and $40 \mathrm{MW}$ when using GEBCO_2014 and ETOPO runs respectively. In the case of Ballenas channel, the annual mean power was estimated to be $150 \mathrm{MW}$ when using the combined bathymetry data, however, the annual mean power was significantly overestimated at around $180 \mathrm{MW}$ when using just ETOPO bathymetry (Table 9).

(a)
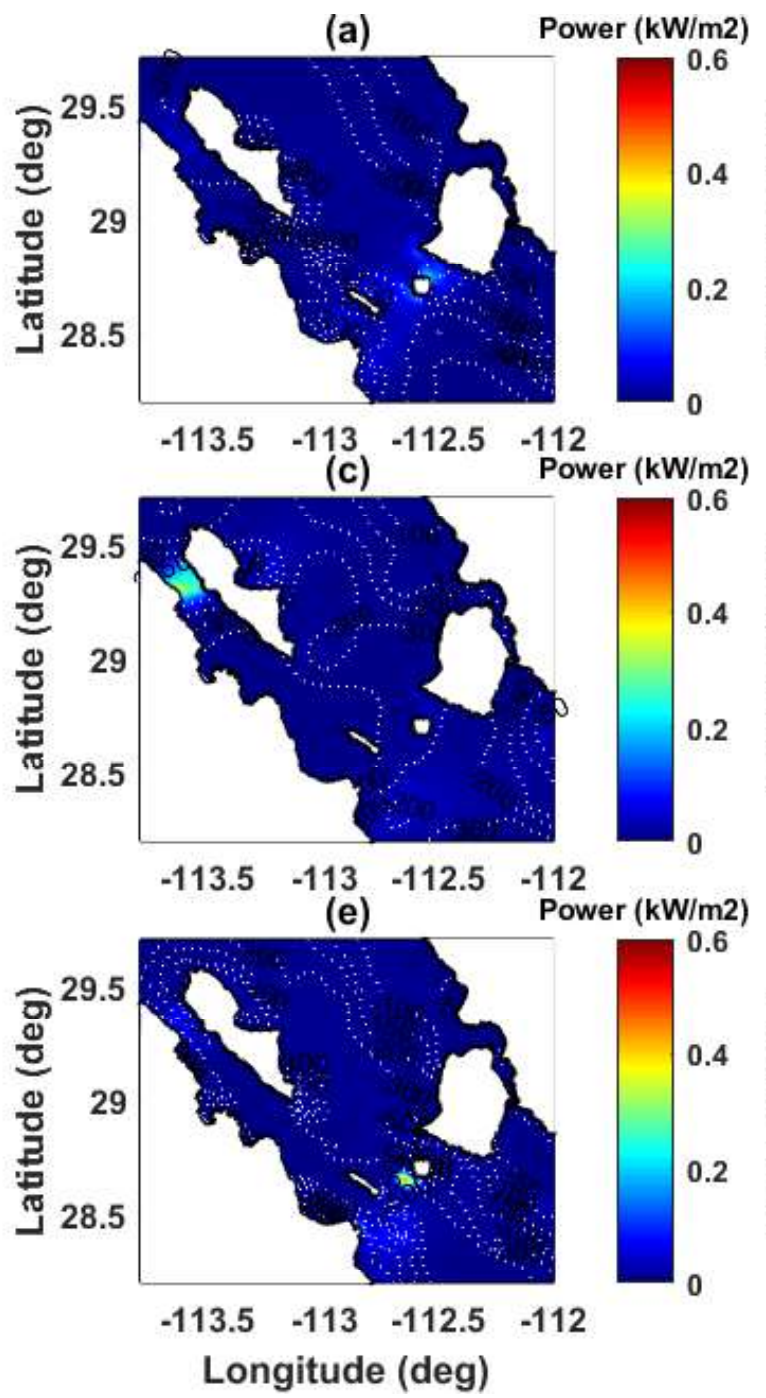

(b)

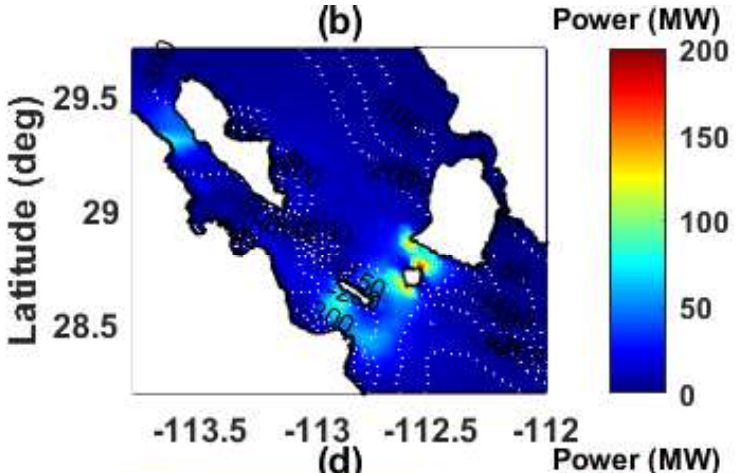

(d)
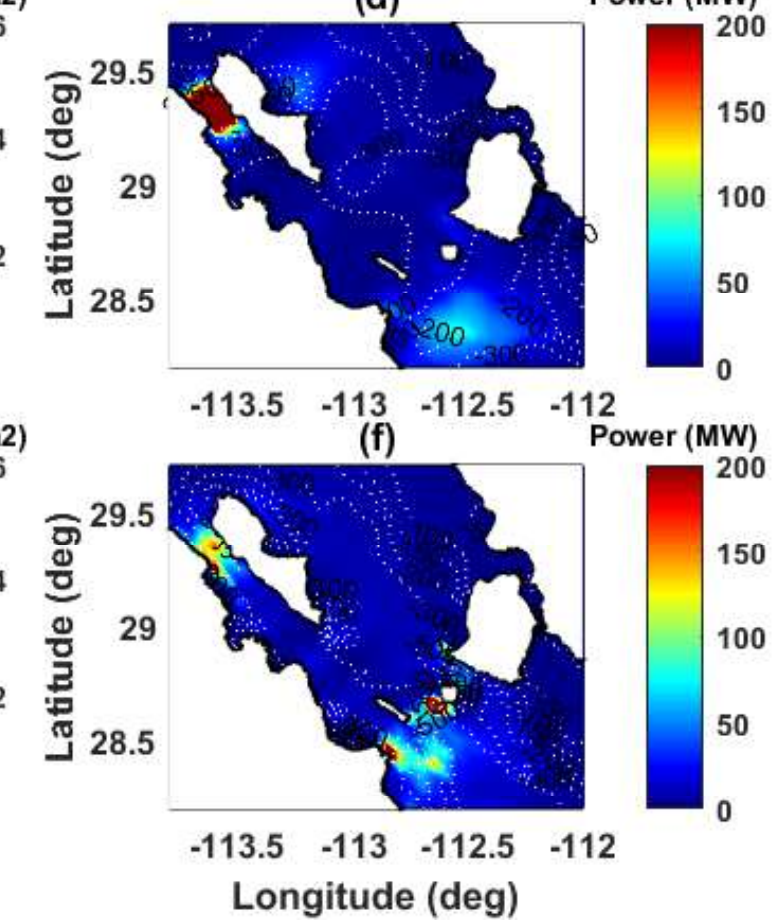

Fig. 10 (a,c,e) Annual mean kinetic power density, (c,f,i) Annual mean power and (b,d,f), (a,b) just GEBCO_2014 data; $(c, d)$ just ETOPO data and $(e, f)$ GEBCO_2014 merged with CICESE, for the Midriff region. Bathymetric contours superimposed in $\mathrm{m}$ above. 

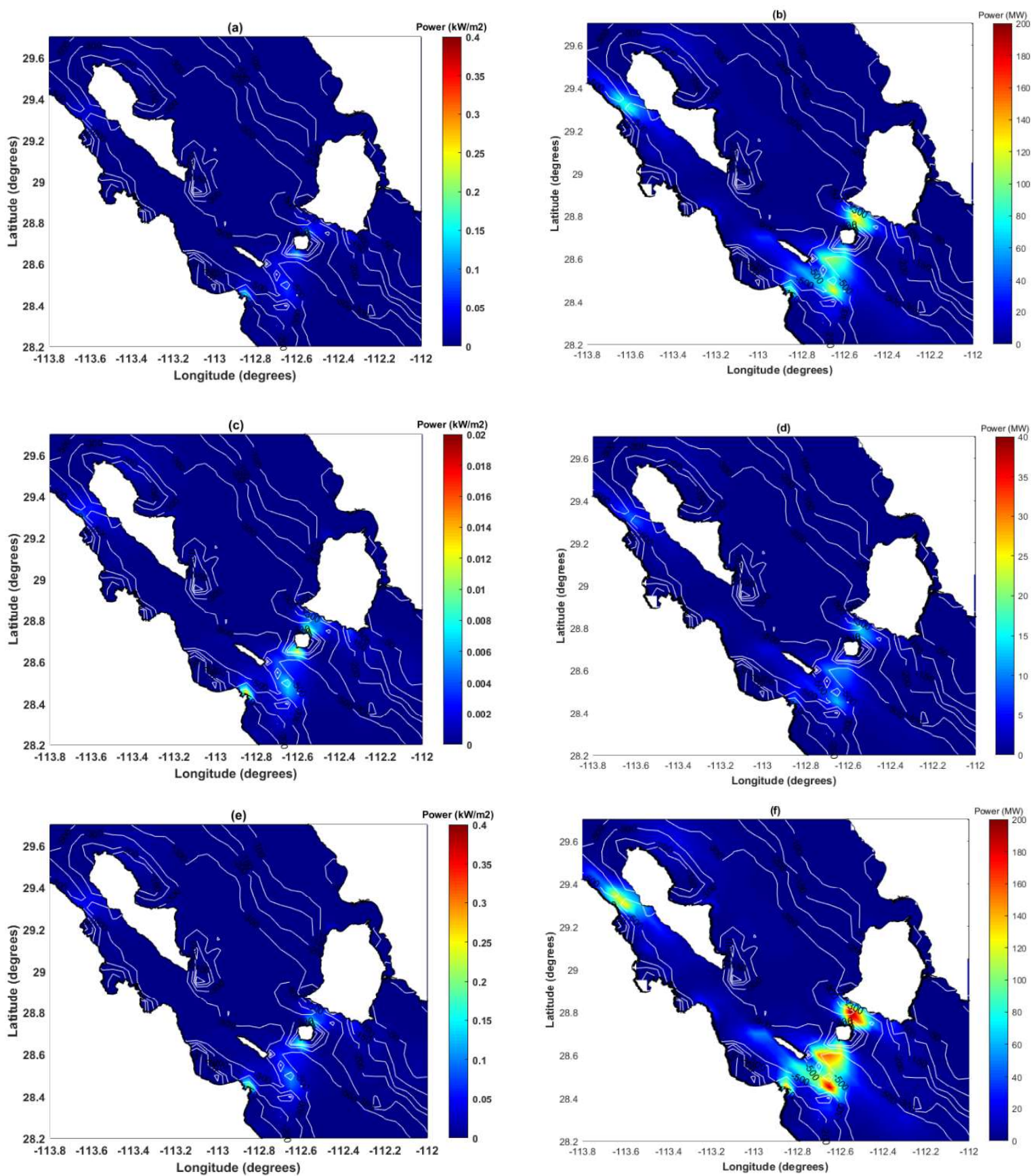

Fig. 11 Annual mean kinetic power density (a) just the $M_{2}$ constituent, (c) $S_{2}$ constituents (e) $M_{2}$ plus $S_{2}$ constituents. Annual theoretical mean power for (b) just the $M_{2}$, (d) $S_{2}$ constituents (f) $M_{2}$ plus $S_{2}$ constituents. All plots use the GEBCO 2014 data merged with the higher resolution data from CICESE, for the Midriff region, for the model bathymetry. Bathymetric contours superimposed in $\mathrm{m}$ above. 
404 Table 9: Annual mean theoretical power (MW) by location using different bathymetry products. Marker Fig. 5a 405 (A) San Lorenzo Passage. (B) channel between the Baja California Peninsula and San Lorenzo, (C) Channel 406 between San Esteban and Tiburon Island and (D) Ballenas Channel between the Baja California Peninsula and 407 Angel de la Guarda Island

\begin{tabular}{cccc}
\hline $\begin{array}{c}\text { Site } \\
\text { Marker }\end{array}$ & GEBCO & ETOPO & $\begin{array}{c}\text { GEBCO merged } \\
\text { with CICESE }\end{array}$ \\
\hline A & $\sim 120$ & $\sim 20$ & $\sim 200$ \\
B & $\sim 80$ & $\sim 40$ & $\sim 160$ \\
C & $\sim 140$ & $\sim 10$ & $\sim 40$ \\
D & $\sim 70$ & $\sim 180$ & $\sim 150$ \\
\hline
\end{tabular}

408

$409 \quad 4.3$ Tidal constituent sensitivity tests

410 In the next stage of testing, we considered how different numbers and combinations of tidal constituents affect

411 the quantification of the tidal-stream energy resource for the GC. Note again, that we did not vary the number of 412 tidal constituents used to force the model boundary; we only varied the number of tidal constituents used to predict 413 a year of tidal currents used for quantifying the tidal-stream energy resource. The results of these tests are shown 414 in Fig.11. The annual mean KPD was first estimated using only the $\mathrm{M}_{2}$ tidal constituent (Fig. 11a). The annual 415 mean KPD was calculated of around 0.18 to $0.08 \mathrm{~kW} / \mathrm{m}^{2}$, while the maximum value reached was calculated as $416 \sim 0.25 \mathrm{~kW} / \mathrm{m}^{2}$ where the fastest currents were occurring (San Lorenzo Passage). Furthermore, significant 417 differences were found where the annual maximum theoretical undisturbed mean power was calculated utilising $418 \mathrm{M}_{2}$ and $\mathrm{S}_{2}$ on their own in San Esteban Passage. Using the $\mathrm{M}_{2}$ tidal constituent, the estimation of the annual power 419 is between 90 and $100 \mathrm{MW}$ (Fig. 11b), while using just the $\mathrm{S}_{2}$ tidal constituents the annual power reduced 420 significantly to around 15 to $20 \mathrm{MW}$ (Fig. 11d). This is because $\mathrm{S}_{2}$ generally is around half that of $\mathrm{M}_{2}$ in the 421 region.

422 Similarly, the annual mean power was calculated using $\mathrm{M}_{2}$ plus $\mathrm{S}_{2}$, where the results indicated an annual mean 423 power range of 140 to $150 \mathrm{MW}$ (Fig. 11f). When considering predicted tidal levels, calculated using all 29 tidal 424 constituents, the maximum annual mean was calculated in San Esteban Passage was $\sim 200 \mathrm{MW}$. The mean annual 425 power reduces significantly to around $70 \%$ using just $\mathrm{M}_{2}$ plus $\mathrm{S}_{2}$ tidal constituent from approximately $200 \mathrm{MW}$ 426 to 140-150 MW. The annual mean power in San between Lorenzo Island and the Baja California peninsula 427 (Marker B on Figure 5a) was calculated between 60 to $70 \mathrm{MW}$ when using the $\mathrm{M}_{2}$ tidal constituent, whereas the 428 annual mean power increased by almost the double (approximately 120 to $130 \mathrm{MW}$ ) when using the $\mathrm{M}_{2}$ plus $\mathrm{S}_{2}$ 429 tidal constituents. Similarly, in the case of Ballenas (Marker D on Fig. 5a) the annual mean power reduces from 43060 to $70 \mathrm{MW}$ when using only $\mathrm{M}_{2}$ to 120 to $130 \mathrm{MW}$ when using $\mathrm{M}_{2}$ plus $\mathrm{S}_{2}$ (Table 10). 
Table 10: Annual mean theoretical power (MW) by location using different tidal constituents with GEBCO merged with CICESE. (A) San Lorenzo Passage. (B) channel between the Baja California Peninsula and San Lorenzo, (C) Channel between San Esteban and Tiburon Island and (D) Ballenas Channel between the Baja California Peninsula and Angel de la Guarda Island

\begin{tabular}{cccc}
$\begin{array}{c}\text { Site } \\
\text { Marker }\end{array}$ & $\mathbf{M}_{\mathbf{2}}$ tidal constituent & $\begin{array}{c}\mathbf{S}_{\mathbf{2}} \text { Tidal } \\
\text { constituent }\end{array}$ & $\begin{array}{c}\mathbf{M}_{\mathbf{2}} \text { plus } \mathbf{S}_{\mathbf{2}} \text { Tidal } \\
\text { constituent }\end{array}$ \\
\hline $\mathrm{A}$ & $90-100 \mathrm{MW}$ & $15-20 \mathrm{MW}$ & $140-150 \mathrm{MW}$ \\
$\mathrm{B}$ & $60-70 \mathrm{MW}$ & $8-10 \mathrm{MW}$ & $120-130 \mathrm{MW}$ \\
$\mathrm{C}$ & $120-130 \mathrm{MW}$ & $10-15 \mathrm{MW}$ & $140-160 \mathrm{MW}$ \\
$\mathrm{D}$ & $60-70 \mathrm{MW}$ & $10-12 \mathrm{MW}$ & $120-130 \mathrm{MW}$ \\
\hline
\end{tabular}

\section{5. Discussion}

440 In this paper, we have conducted two different sensitivity tests, as follows: (1) using three different bathymetry 441 products that were a combination of open source data and bespoke surveys; and (2) including different numbers 442 and combinations of tidal constituents, when predicting tidal levels and quantifying the tidal energy resource. In 443 the bathymetry sensitivity test, we compared three different bathymetry products which resulted in either an over 444 or under-estimation of the resource. We utilized exactly the same mesh resolution within the three simulations. 445 Thus, the computational mesh resolved the resource equally as well as the current speeds. Therefore, we assumed 446 that the changes of the resource are related to the bathymetry data which allow the water to be squeezed through 447 a smaller channel. Furthermore, the distribution of the water within the domain area especially in the narrow 448 channels within the midriff region would be different.

449 We considered four locations where current speeds are highest. At markers A, B and D (in Figure 5a) the annual 450 mean power as underestimated by more than a half, whereas at location $\mathrm{C}$ the annual mean power was 451 overestimated when using GEBCO_2014 only in comparison with GEBCO_2014 bathymetry merged with 452 CICESE. We find therefore that global and freely available bathymetry data products under-resolve the resource 453 by $75 \%$. For the location with fastest current speeds at San Lorenzo Passage, the annual mean power was 454 estimated to be around $50 \mathrm{MW}$ when using freely available bathymetry data (GEBCO and ETOPO), while the 455 annual mean power increased to $\sim 200 \mathrm{MW}$ when using a bespoke dataset that was a combination of GEBCO and 456 higher resolution bathymetry provided by CICESE.

457 Uncertainty in tidal-stream resource estimation has been the focus for other geographic regions for good reason.

458 For example, two studies of the Johnstone Strait (British Columbia, Canada) found the annual mean tidal-stream 459 resource varied between $4015 \mathrm{MW}$ [24] and $1320 \mathrm{MW}$ [25] when using different bathymetry products. The main 460 differences in the estimated energy resource within this region could be a result of the use of different bathymetry 461 products, however, part of the differences could also be as a result of using differing methodologies to assess the site. A study carried out by [26] concluded the flow constrains as a result of the bathymetry data, where the 463 coefficient of variation in the Florida Current is approximately $0.3 \%$, resulted in a slight flow reduction. Similarly, 464 a study by [27] stated that the bathymetry data would alter the local tidal currents along Ireland's coastline; consequently, the tidal current resource could vary significantly. Another study refers to the variability of the 
power as a result of the velocity changes due to the bathymetry data [28]. They state that a combination of seabed

467 bathymetries and coastal shapes within the near-shore site in the Iroise Sea on the western Brittany coast, France can alter the hydrodynamics and consequently the power density estimated can change.

469 In regard to tidal constituents, we compared the energy resource estimated using tidal levels predicted from 29 470 tidal constituents with time-series predicting just included the $\mathrm{M}_{2}$ and $\mathrm{S}_{2}$ tidal constitutes. The annual mean KPD 471 decreased by almost $1 / 3^{\text {rd }}$ in San Lorenzo Passage, when just considering the $M_{2}$ plus $S_{2}$ constituents, suggesting 472 that diurnal and higher order harmonic constituents are important for accurate resource assessments in this region. 473 In the sensitivity tests, in which we compared the estimated energy estimates using all the constituents and just

$474 \quad \mathrm{M}_{2}$ plus $\mathrm{S}_{2}$, the annual mean KPD had relatively large differences. The resource decreased by almost $1 / 3^{\text {rd }}$ in San 475 Lorenzo Passage when using only the $\mathrm{M}_{2}$ tidal constituents. Similarly, within the region of Ballenas channel the 476 annual mean power reduced significantly from $140 \mathrm{MW}$, when using all 29 tidal constituents, to $70 \mathrm{MW}$ when 477 using only the $\mathrm{M}_{2}$ tidal constituent. The variability of the resource using a limited number of tidal constituents to 478 predict the tidal current annually indicates that the $\mathrm{M}_{2}$ constituent, as expected, plays an important role in the 479 energy calculation and contributes more than $50 \%$ of the total energy resource, while $\mathrm{S}_{2}$ contributes less ( $\left.\sim 20 \%\right)$. 480 Therefore, the results suggested that diurnal and higher order harmonic constituents are important for accurate 481 resource assessments in this region.

482 A clear example of the variability of the energy resource when only $\mathrm{M}_{2}$ and $\mathrm{S}_{2}$ tidal constituents where used is 483 highlighted in a study by [29]. The theoretical undisturbed kinetic power density was estimated to be around 9 $484 \mathrm{~kW} / \mathrm{m}^{2}$ at Casquets which is located in the Channel Islands (West of Alderney) when using just $\mathrm{M}_{2}$ plus $\mathrm{S}_{2}$ tidal constituents. While an assessment carried out by [19] estimated the kinetic power density (in the same region and utilizing the same methodology) of $7 \mathrm{~kW} / \mathrm{m}^{2}$ when using only the $\mathrm{M}_{2}$ tidal constituent. Therefore, these results pointed out that the kinetic power density was underestimated by $20 \%$ when using only the $\mathrm{M}_{2}$ tidal constituents. Annual power variability using multiple tidal constituents was also assessed by Adcock et al. [30 and 31] where the annual mean power was calculated in Pentland Firth, UK. The first paper (in 2013) estimated a mean power of $1.9 \mathrm{GW}$ when using $\mathrm{M}_{2}$ plus $\mathrm{S}_{2}$ tidal constituent, whereas a subsequent study conducted by the same authors (in 2014) included eight main tidal constituents $\left(\mathrm{K}_{1}, \mathrm{~K}_{2}, \mathrm{M}_{2}, \mathrm{MU}_{2}, \mathrm{~N}_{2}, \mathrm{NU}_{2}, \mathrm{O}_{1}\right.$ and $\left.\mathrm{S}_{2}\right)$. The results by [31] indicated that the maximum available mean power is $2.16 \mathrm{GW}$ while using only $\mathrm{M}_{2}$ and $\mathrm{M}_{2}$ plus $\mathrm{S}_{2}$ tidal constituents, the annual power reduces by approximately $20 \%(1.74 \mathrm{GW})$ and $5 \%(2.15 \mathrm{GW})$, respectively.

\section{Conclusions}

496 To quantify the tidal-stream energy resource in any given region requires accurate bathymetry and hydrodynamic 497 processes. These need to be quantified and best practices identified. The best model validation against tide gauge 498 and ADCP measurements was obtained using the bespoke merged GEBCO and CICESE bathymetric dataset. 499 Model simulations using the merged bathymetry data predicted peak current speeds of up to $2.4 \mathrm{~m} / \mathrm{s}$ in San 500 Lorenzo Passage whereas the maximum current speed using ETOPO alone was less than $1 \mathrm{~m} / \mathrm{s}$ in San Lorenzo 501 Passage. In comparison, using bathymetry, model simulations predicted $1 \mathrm{~m} / \mathrm{s}$ in the Ballenas channel and the maximum current speed increased to $1.8 \mathrm{~m} / \mathrm{s}$, when using just ETOPO. We concluded that the tidal-stream resource of the Gulf of California was higher when using higher-resolution bathymetry products, which has interesting applications for the potential global resource and tidal energy industry. The number and combination 
505 of tidal constituents used, also affected the annual energy estimations. In San Lorenzo passage. the annual mean 506 power varied from 15-20 MW, 90-100 MW and 140-150 MW, when using just the $\mathrm{M}_{2}$ constituent, just $\mathrm{S}_{2}$ and $\mathrm{M}_{2}$ 507 plus $\mathrm{S}_{2}$, respectively. When using all 29 tidal constituents the annual mean power was estimated to be $\sim 200 \mathrm{MW}$.

508 In conclusion, the results from this study indicate that it would be advisable to validate different bathymetry 509 products in order to ascertain accurate velocities at any given region. This validation should include the main 510 semi-diurnal and diurnal constituents to define the specific tidal-stream energy resource at any given site.

511

\section{Acknowledgements}

513 We thank Dr. Silvio Guido Marinone and Dr. Antonio Gonzalez Fernandez from CICESE research centre for 514 providing the higher resolution bathymetry data for the Gulf of California and Dr. Manuel Lopez from CICESE 515 for the ADCP dataset. This research was financed by two sponsorships: CONACyT (the National Council of 516 Science and Technology) through the grant "Becas en el extranjero 2014-1" grant reference CVU 536867 and by 517 the University of Southampton.

518 


\section{References}

[1] Bahaj, A. S., \& Myers, L. (2004). Analytical estimates of the energy yield potential from the Alderney Race (Channel Islands) using marine current energy converters. Renewable Energy, 29(12), 1931-1945. doi:http://dx.doi.org/10.1016/j.renene.2004.02.013

[2] Bahaj, A. S. (2011). Generating electricity from the oceans. Renewable and Sustainable Energy Reviews, 15(7), 3399-3416. doi:https://doi.org/10.1016/j.rser.2011.04.032.

[3] Neill, S. P., Angeloudis, A., Robins, P. E., Walkington, I., Ward, S. L., Masters, I., . . Falconer, R. (2018). Tidal range energy resource and optimization - Past perspectives and future challenges. Renewable Energy, 127, 763-778. doi:https://doi.org/10.1016/j.renene.2018.05.007.

[4] Myers, L., \& Bahaj, A. S. (2005). Simulated electrical power potential harnessed by marine current turbine arrays in the Alderney Race. Renewable Energy, 30(11), 1713-1731. doi:http://dx.doi.org/10.1016/j.renene.2005.02.008.

[5] Sutherland, G., Foreman, M., \& Garrett, C. (2007). Tidal current energy assessment for Johnstone Strait, Vancouver Island. Proceedings of the Institution of Mechanical Engineers, Part A: Journal of Power and Energy, 221(2), 147-157. doi:10.1243/09576509jpe338

[6] Blanchfield, J., Garrett, C., Rowe, A., \& Wild, P. (2008). Tidal Stream power resource assessment for Masset Sound, Haida Gwaii. Proceedings of the Institution of Mechanical Engineers, Part A: Journal of Power and Energy, 222(5), 485-492. doi:10.1243/09576509jpe585

[7] Draper, S., Adcock, T. A. A., Borthwick, A. G. L., \& Houlsby, G. T. (2014). Estimate of the tidal stream power resource of the Pentland Firth. Renewable Energy, 63, 650-657. doi:https://doi.org/10.1016/j.renene.2013.10.015

[8] Mejia-Olivares, C. J., Haigh, I. D., Wells, N. C., Coles, D. S., Lewis, M. J., \& Neill, S. P. (2018). Tidal-stream energy resource characterization for the Gulf of California, México. Energy, 156, 481-491. doi:https://doi.org/10.1016/j.energy.2018.04.074

[9] Badan-Dangon, A., Lavin, M. F., and Hendershott, M. C. (1991), Underway Doppler current profiles in the Gulf of California, Eos Trans. AGU, 72( 19), 209-218, doi:10.1029/EO072i019p00209-01.

[10] López, M., Candela, J., \& García, J. (2008). Two overflows in the Northern Gulf of California. Journal of Geophysical Research: Oceans, 113(C8), n/a-n/a. doi:10.1029/2007JC004575

[11] Myers LE. Internal Report, Department of Civil and Environmental Engineering, University of Southampton, 2003.

[12] Iyer, A. S., Couch, S. J., Harrison, G. P., \& Wallace, A. R. (2013). Variability and phasing of tidal current energy around the United Kingdom. Renewable Energy, 51(Supplement C), 343-357. doi:https://doi.org/10.1016/j.renene.2012.09.017

[13] Lewis, M., Neill, S. P., Robins, P. E., \& Hashemi, M. R. (2015). Resource assessment for future generations of tidal-stream energy arrays. Energy, 83, 403-415. doi:http://dx.doi.org/10.1016/j.energy.2015.02.038

[14] Kapoor, D.C., (1981). General bathymetric chart of the oceans (GEBCO). Marine Geodesy, 5(1), pp.73-80.

[15]NOAA (2017). ETOPO1 Global Relief Model [online] United States of America. Available from https://www.ngdc.noaa.gov/mgg/global/. [Accessed March 2017].

[16] Jean-Michel Hervouet, "Hydrodynamics of Free Surface Flows: Modelling with the Finite Element Method", Wiley Blackwell, April 2007, 360p, ISBN-13: 978-0470035580.

[17] Blunden, L. S., \& Bahaj, A. S. (2006). Initial evaluation of tidal stream energy resources at Portland Bill, UK. Renewable Energy, 31(2), 121-132. doi:http://dx.doi.org/10.1016/j.renene.2005.08.016

[18] Cornett, A., Durand, N., \& Serrer, M. (2010). 3-D Modelling and Assessment of Tidal Current Resources in the Bay of Fundy, Canada.

[19] Coles, D. S., Blunden, L. S., \& Bahaj, A. S. (2017). Assessment of the energy extraction potential at tidal sites around the Channel Islands. Energy, 124(Supplement C), 171-186. doi:https://doi.org/10.1016/j.energy.2017.02.023 
[20] Pawlowicz, R., Beardsley, B., \& Lentz, S. (2002). Classical tidal harmonic analysis including error estimates in MATLAB using T_TIDE. Computers \& Geosciences, 28(8), 929-937. doi:https://doi.org/10.1016/S0098-3004(02)00013-4

[21] Lang, P., 2010. TELEMAC modelling system User Manual, EDF- R\&D.

570

571

572

573

574

575

576

577

578

579

580

581

582

583

584

585

586

587

588

589

590

591

592

593

594

595

596

597

598

599

600

601

602

603

604

605

606

607

608

609

610

611

612

613

614
[22] Egbert, G. D., Bennett, A. F., \& Foreman, M. G. G. (1994). TOPEX/POSEIDON tides estimated using a global inverse model. Journal of Geophysical Research: Oceans, 99(C12), 24821-24852. doi:10.1029/94JC01894

[23] Egbert, G. D., \& Erofeeva, S. Y. (2002). Efficient Inverse Modeling of Barotropic Ocean Tides. Journal of Atmospheric and Oceanic Technology, 19(2), 183-204. doi:10.1175/15200426(2002)019<0183:eimobo $>2.0 . c 0 ; 2$

[24] Tarbotton, M., \& Larson, M. (2006). Canada ocean energy atlas (phase 1) potential tidal current energy resources analysis background. Report to Canadian Hydraulics Centre.

[25] Sutherland, G., Foreman, M., \& Garrett, C. (2007). Tidal current energy assessment for Johnstone Strait, Vancouver Island. Proceedings of the Institution of Mechanical Engineers, Part A: Journal of Power and Energy, 221(2), 147-157. doi:10.1243/09576509jpe338

[26] Georgia Tech Research Corporation, (2011). Assessment of Energy Production Potential from Tidal Streams in the United States. Final Project Report June 29, 2011. Award Number: DE-FG36-08GO18174.

[27] O’Rourke, F., Boyle, F., \& Reynolds, A. (2014). Ireland's tidal energy resource; An assessment of a site in the Bulls Mouth and the Shannon Estuary using measured data. Energy Conversion and Management, 87, 726-734. doi:http://dx.doi.org/10.1016/j.enconman.2014.06.089

[28] Thiébaut, M., \& Sentchev, A. (2015). Estimation of Tidal Stream Potential in the Iroise Sea from Velocity Observations by High Frequency Radars. Energy Procedia, 76, 17-26. doi:http://dx.doi.org/10.1016/j.egypro.2015.07.835

[29] Guillou, N., Neill, S. P., \& Robins, P. E. (2018). Characterising the tidal stream power resource around France using a high-resolution harmonic daase. Renewable Energy, 123, 706-718. doi:https://doi.org/10.1016/j.renene.2017.12.033

[30] Adcock, T. A. A., Draper, S., Houlsby, G. T., Borthwick, A. G. L., \& Serhadlıoglu, S. (2013). The available power from tidal stream turbines in the Pentland Firth. Proceedings of the Royal Society A: Mathematical, Physical and Engineering Science, 469(2157). doi:10.1098/rspa.2013.0072

[31] Adcock, T. A., Draper, S., Houlsby, G. T., Borthwick, A. G., \& Serhadlığlu, S. (2014). Tidal stream power in the Pentland Firth - long-term variability, multiple constituents and capacity factor. Proceedings of the Institution of Mechanical Engineers, Part A: Journal of Power and Energy, 228(8), 854-861. doi: $10.1177 / 0957650914544347$

[32] Hagerman, G., Polagye, B., Bedard, R., \& Previsic, M. (2006). Methodology for estimating tidal current energy resources and power production by tidal in-stream energy conversion (TISEC) devices.

[33] Cornett A. (2006), Inventory of Canada's Marine renewable energy resources. Canadian Hydraulics centre. CHC-TR-041. April 2006.

[34] O'Rourke, F., Boyle, F., \& Reynolds, A. (2010). Tidal current energy resource assessment in Ireland: Current status and future update. Renewable and Sustainable Energy Reviews, 14(9), 3206-3212. doi:http://dx.doi.org/10.1016/j.rser.2010.07.039

[35] Georgia Tech Research Corporation, (2011). Assessment of Energy Production Potential from Tidal Streams in the United States. Final Project Report June 29, 2011. Award Number: DE-FG36-08GO18174.

[36] Karsten, R., Swan, A., \& Culina, J. (2013). Assessment of arrays of in-stream tidal turbines in the Bay of Fundy. Philosophical Transactions of the Royal Society A: Mathematical, Physical and Engineering Sciences, 371(1985). doi:10.1098/rsta.2012.0189

[37] Georgia Tech Research Corporation, (2013). Assessment of Energy Production Potential from Ocean Currents along the United States Coastline. Final Project Report September 15, 2013. Award Number: DE-EE0002661. (MFanually edited). 
[38] Serhadlığlu, S., Adcock, T. A. A., Houlsby, G. T., Draper, S., \& Borthwick, A. G. L. (2013). Tidal stream energy resource assessment of the Anglesey Skerries. International Journal of Marine Energy, 3-4, e98e111. doi:https://doi.org/10.1016/j.ijome.2013.11.014

[39] Work, P. A., Haas, K. A., Defne, Z., \& Gay, T. (2013). Tidal stream energy site assessment via threedimensional model and measurements. Applied Energy, 102(Supplement C), 510-519. doi:https://doi.org/10.1016/j.apenergy.2012.08.040

[40] Blunden, L. S., Bahaj, A. S., \& Aziz, N. S. (2013). Tidal current power for Indonesia? An initial resource estimation for the Alas Strait. Renewable Energy, 49, 137-142. doi:https://doi.org/10.1016/j.renene.2012.01.046

[41] Plew, D. R., \& Stevens, C. L. (2013). Numerical modelling of the effect of turbines on currents in a tidal channel - Tory Channel, New Zealand. Renewable Energy, 57, 269-282. doi:http://dx.doi.org/10.1016/j.renene.2013.02.001

[42] Wang, T., \& Yang, Z. (2017). A modelling study of tidal energy extraction and the associated impact on tidal circulation in a multi-inlet bay system of Puget Sound. Renewable Energy. doi:http://dx.doi.org/10.1016/j.renene.2017.03.049

[43] Tang, H. S., Qu, K., Chen, G. Q., Kraatz, S., Aboobaker, N., \& Jiang, C. B. (2014). Potential sites for tidal power generation: A thorough search at coast of New Jersey, USA. Renewable and Sustainable Energy Reviews, 39, 412-425. doi:https://doi.org/10.1016/j.rser.2014.07.051

[44] Osorio, A. F., Ortega, S., \& Arango-Aramburo, S. (2016). Assessment of the marine power potential in Colombia. Renewable and Sustainable Energy Reviews, 53, 966-977. doi:http://dx.doi.org/10.1016/j.rser.2015.09.057

[45] González-Gorbeña, E., Rosman, P. C. C., \& Qassim, R. Y. (2015). Assessment of the tidal current energy resource in São Marcos Bay, Brazil. Journal of Ocean Engineering and Marine Energy, 1(4), 421-433. doi:10.1007/s40722-015-0031-5

[46] Orhan, K., Mayerle, R., \& Pandoe, W. W. (2015). Assesment of Energy Production Potential from Tidal Stream Currents in Indonesia. Energy Procedia, 7-16. doi:http://dx.doi.org/10.1016/j.egypro.2015.07.834

[47] Goward Brown, A. J., Neill, S. P., \& Lewis, M. J. (2017). Tidal energy extraction in three-dimensional ocean models. Renewable Energy. doi:http://dx.doi.org/10.1016/j.renene.2017.04.032

[48] Alonso, R., Jackson, M., Santoro, P., Fossati, M., Solari, S., \& Teixeira, L. (2017). Wave and tidal energy resource assessment in Uruguayan shelf seas. Renewable Energy. doi:http://dx.doi.org/10.1016/j.renene.2017.03.074.

[49] Marta-Almeida, M., Cirano, M., Guedes Soares, C., \& Lessa, G. C. (2017). A numerical tidal stream energy assessment study for Baía de Todos os Santos, Brazil. Renewable Energy, 107, 271-287. doi:https://doi.org/10.1016/j.renene.2017.01.047

[50] Thiébaut, M., \& Sentchev, A. (2017). Asymmetry of tidal currents off the W.Brittany coast and assessment of tidal energy resource around the Ushant Island. Renewable Energy, 105, 735-747. doi:http://dx.doi.org/10.1016/j.renene.2016.12.082

[51] Campbell, R., Martinez, A., Letetrel, C., \& Rio, A. (2017). Methodology for estimating the French tidal current energy resource. International Journal of Marine Energy, 19(Supplement C), 256-271. doi:https://doi.org/10.1016/j.ijome.2017.07.011 
Appendix A Table 1 List of studies that mentioned and used one or more different

\begin{tabular}{|c|c|c|c|c|}
\hline Location & $\begin{array}{c}\text { Current } \\
\text { speed }\end{array}$ & Modelling approach & Bathymetry used & Reference \\
\hline $\begin{array}{l}\text { USA, East and } \\
\text { west coast. }\end{array}$ & $\begin{array}{l}\text { From } 1.5 \\
\text { up to } 6.67 \\
\mathrm{~m} / \mathrm{s}\end{array}$ & WXTide 32 & $\begin{array}{c}\text { National Oceanic and } \\
\text { Atmospheric Administration } \\
\text { NOAA, USA }\end{array}$ & {$[32]$} \\
\hline $\begin{array}{l}\text { Canada, East and } \\
\text { west coast. }\end{array}$ & $\begin{array}{l}\text { average } \\
\text { flow speed } \\
\text { of } 2.11 \mathrm{~m} / \mathrm{s}\end{array}$ & $\begin{array}{l}\text { WebTide Tidal } \\
\text { Prediction Model } \\
\text { (v0.7.1) }\end{array}$ & $\begin{array}{l}\text { Canadian Hydrographic Service, } \\
\text { admiralty charts by Nautical } \\
\text { Data International (NDI). }\end{array}$ & [33] \\
\hline $\begin{array}{l}\text { Canada } \\
\text { Northwest } \\
\text { Territories } \\
\text { British Columbia } \\
\text { Quebec } \\
\text { Nunavut } \\
\text { New Brunswick } \\
\text { PEI } \\
\text { Nova Scotia } \\
\text { Newfoundland }\end{array}$ & $\begin{array}{c}\text { From } 2.7 \\
\mathrm{~m} / \mathrm{s} \text { to } 8.23 \\
\mathrm{~m} / \mathrm{s} . \text { Please } \\
\text { see } \\
\text { reference } \\
\text { for full } \\
\text { details }\end{array}$ & Tide 2D & $\begin{array}{c}\text { Nautical data including } \\
\text { Canadian Sailing Directions and } \\
\text { a total of } 950 \text { nautical charts by } \\
\text { The Canadian Hydrographic } \\
\text { Service }\end{array}$ & [24] \\
\hline UK, Portland Bill & $3.6 \mathrm{~m} / \mathrm{s}$ & TELEMAC 2D & $\begin{array}{l}\text { Southampton Oceanography } \\
\text { Centre bathymetry survey }\end{array}$ & [17] \\
\hline $\begin{array}{l}\text { Canada, Johnstone } \\
\text { Strait }\end{array}$ & $\begin{array}{c}4.7 \text { to } 7.7 \\
\mathrm{~m} / \mathrm{s}\end{array}$ & TIDE2D & $\begin{array}{c}\text { Canadian Hydrographic Service } \\
\text { and the National Oceanic and } \\
\text { Atmospheric } \\
\text { Administration NOAA, USA. }\end{array}$ & {$[25]$} \\
\hline $\begin{array}{l}\text { Masset Sound, } \\
\text { located in Haida } \\
\text { Gwaii }\end{array}$ & $2.5 \mathrm{~m} / \mathrm{s}$ & $\begin{array}{l}\text { One-dimensional } \\
\text { model }\end{array}$ & $\begin{array}{c}\text { Bathymetry data provided by } \\
\text { Canadian Hydrographic Service } \\
\text { department of fishery and } \\
\text { oceans }\end{array}$ & {$[6]$} \\
\hline $\begin{array}{l}\text { Bay of Fundy, } \\
\text { Canada }\end{array}$ & $\begin{array}{l}\text { Average } \\
\text { spring tide } \\
\text { excess } 5 \\
\mathrm{~m} / \mathrm{s}\end{array}$ & TELEMAC 3D & $\begin{array}{l}\text { High-resolution bathymetric by } \\
\text { Natural Resources } \\
\text { Canada using a multi-beam } \\
\text { sonar. Bathymetric contours by } \\
\text { the Canadian hydrographic } \\
\text { service and various data sets } \\
\text { collected by Massachusetts } \\
\text { Geographic Information } \\
\text { System. }\end{array}$ & [18] \\
\hline Ireland & $\begin{array}{c}\text { Above } 1.9 \\
\mathrm{~m} / \mathrm{s}\end{array}$ & MIKE 21 & $\begin{array}{l}\text { local bathymetry provided by } \\
\text { the Danish Hydrographic } \\
\text { Institute }\end{array}$ & [34] \\
\hline $\begin{array}{l}\text { Georgia Coast, } \\
\text { USA }\end{array}$ & $\begin{array}{c}\text { Mean from } \\
0.34 \text { to } 1.07 \\
\mathrm{~m} / \mathrm{s}\end{array}$ & ROMS & $\begin{array}{c}\text { The medium resolution } \\
\text { shoreline }(1 / 70,000) \text { data from } \\
\text { National. } \\
\text { Oceanic and Atmospheric } \\
\text { Administration (NOAA) and the } \\
\text { digital } \\
\text { sounding data from National } \\
\text { Geophysical Data Centre } \\
\text { (NGDC) } \\
\end{array}$ & {$[41]$} \\
\hline USA coastline & $1 \mathrm{~m} / \mathrm{s}$ & ROMS & $\begin{array}{l}\text { Hydrographic Surveys Database } \\
\text { (NOS, 2008a). NOAA } \\
\text { Electronic Navigational Charts } \\
\text { (NOAA, 2008a) and National } \\
\text { Geophysical Data Centre } \\
\text { Geophysical Data System } \\
\text { database (GEODAS) (NGDC). }\end{array}$ & [35] \\
\hline $\begin{array}{l}\text { Canada, Bay of } \\
\text { Fundy }\end{array}$ & $\begin{array}{l}\text { More than } \\
5 \mathrm{~m} / \mathrm{s}\end{array}$ & FVCOM & $\begin{array}{l}\text { Survey by Bedford Institute of } \\
\text { Oceanography and the } \\
\text { bathymetry used by Tarbotton } \\
\text { and Larson (2006). Triton } \\
\text { consultants }\end{array}$ & {$[36]$} \\
\hline Coastline, USA & & $\begin{array}{l}\text { HYCOM, ROMS, } \\
\text { HYCOM GLOBAL, } \\
\text { NCOM }\end{array}$ & $\begin{array}{c}\text { National Oceanic and } \\
\text { Atmospheric Administration } \\
\text { NOAA, USA }\end{array}$ & [37] \\
\hline
\end{tabular}




\begin{tabular}{|c|c|c|c|c|}
\hline Location & $\begin{array}{l}\text { Current } \\
\text { speed }\end{array}$ & Modelling approach & Bathymetry used & Reference \\
\hline UK, Pentland Firth & $5 \mathrm{~m} / \mathrm{s}$ & ADCIRC & $\begin{array}{l}\text { The bathymetry data were } \\
\text { purchased from Seazone. } \\
\text { http://www.seazone.com/ }\end{array}$ & [30] \\
\hline $\begin{array}{l}\text { UK, Anglesey } \\
\text { Skerries }\end{array}$ & $\begin{array}{l}\text { Up to } 1.4 \\
\mathrm{~m} / \mathrm{s}\end{array}$ & ADCIRC & $\begin{array}{l}\text { Bathymetry data provided by } \\
\text { Seazone. } \\
\text { http://www.seazone.com/ }\end{array}$ & {$[38]$} \\
\hline $\begin{array}{l}\text { South Carolina, } \\
\text { USA }\end{array}$ & $0.87 \mathrm{~m} / \mathrm{s}$ & ROMS 3D & $\begin{array}{l}\text { US National Ocean Service data } \\
\text { and boat surveys }\end{array}$ & [39] \\
\hline $\begin{array}{l}\text { Indonesia, Alas } \\
\text { strait }\end{array}$ & $1.2 \mathrm{~m} / \mathrm{s}$ & $\begin{array}{l}\text { The Princeton Ocean } \\
\text { Model (POM) }\end{array}$ & $\begin{array}{l}\text { Bathymetric chart of Alas Strait } \\
\text { (map } \\
\text { Number 293, edition 2006) } \\
\text { provided by Indonesian Navy } \\
\text { Hydro-Oceanographic Division. }\end{array}$ & {$[40]$} \\
\hline $\begin{array}{l}\text { New Zealand, Tory } \\
\text { Channel }\end{array}$ & $2 \mathrm{~m} / \mathrm{s}$ & RICOM & $\begin{array}{c}\text { Swath bathymetry and digitizing } \\
\text { of contours and soundings from } \\
\text { the Land Information New } \\
\text { Zealand Hydrographic Charts } \\
\text { (NZ 463, } \\
4633,614 \mathrm{e} 615,6142 \\
6151 \mathrm{e} 6154,6212 \text { ). }\end{array}$ & [41] \\
\hline $\begin{array}{l}\text { Puget Sound, } \\
\text { Canada }\end{array}$ & $\begin{array}{c}2 \mathrm{~m} / \mathrm{s} \\
\text { during } \\
\text { spring tide }\end{array}$ & FVCOM & $\begin{array}{l}\text { Bathy from digital elevation } \\
\text { model and light detection and } \\
\text { ranging (LiDAR). }\end{array}$ & {$[42]$} \\
\hline Pentland Firth, UK & $3 \mathrm{~m} / \mathrm{s}$ & ADCIRC & $\begin{array}{c}\text { The bathymetry data was the } \\
\text { same as Adcock et al. (2013). } \\
\text { purchased from Seazone } \\
\text { http://www.seazone.com/ }\end{array}$ & [31] \\
\hline $\begin{array}{l}\text { Ireland, Bull mouth } \\
\text { and Shannon } \\
\text { Estuary. }\end{array}$ & $\begin{array}{c}2.02 \mathrm{~m} / \mathrm{s} \\
\text { during } \\
\text { spring tide }\end{array}$ & Measure data & No provided information & [27] \\
\hline $\begin{array}{l}\text { Coast of New } \\
\text { jersey, USA } \\
\text { (please see } \\
\text { reference for } \\
\text { details of the } 21 \\
\text { points) }\end{array}$ & $1.26 \mathrm{~m} / \mathrm{s}$ & $\begin{array}{c}\text { Finite Volume Coastal } \\
\text { Ocean Model } \\
\text { (FVCOM) }\end{array}$ & $\begin{array}{l}\text { NOAA Coastal Services Centre } \\
\text { and ETOP5. }\end{array}$ & {$[43]$} \\
\hline $\begin{array}{l}\text { Colombia, } \\
\text { Buenaventura Bay. }\end{array}$ & $\begin{array}{c}\text { Mean } \\
\text { current } \\
\text { speed } 0.8 \\
\mathrm{~m} / \mathrm{s}\end{array}$ & $\mathrm{H} 2 \mathrm{D}$ & $\begin{array}{c}\text { ETOPO1 and Sistema de } \\
\text { Modelado costero (SMC) } \\
\text { bathymetry module from } \\
\text { University of Cantabria Spain. }\end{array}$ & [44] \\
\hline $\begin{array}{l}\text { Brazil, Sao Marcos } \\
\text { Bay. }\end{array}$ & $2.63 \mathrm{~m} / \mathrm{s}$ & SisBaHiA & $\begin{array}{l}\text { Digitising nautical charts for } \\
\text { São Marcos Bay }\end{array}$ & {$[45]$} \\
\hline UK, Irish Sea & $\begin{array}{c}\text { Above } 2.5 \\
\mathrm{~m} / \mathrm{s}\end{array}$ & ROMS & $\begin{array}{c}\text { Digitised Admiralty data. } \\
\text { (http://digimap.edina.ac. } \\
\text { uk) }\end{array}$ & [13] \\
\hline $\begin{array}{l}\text { Indonesia, Strait of } \\
\text { Larantuka }\end{array}$ & 3 to $4 \mathrm{~m} / \mathrm{s}$ & Delft3D & GEBCO 30 arc-second & {$[46]$} \\
\hline Pentland, Firth UK & $2 \mathrm{~m} / \mathrm{s}$ & ROMS & GEBCO 30 arc-second & {$[47]$} \\
\hline $\begin{array}{l}\text { Puget Sound, } \\
\text { Canada }\end{array}$ & $\begin{array}{c}2 \mathrm{~m} / \mathrm{s} \\
\text { during } \\
\text { spring tide }\end{array}$ & FVCOM & $\begin{array}{l}\text { Bathy from digital elevation } \\
\text { model and light detection and } \\
\text { ranging (LiDAR). }\end{array}$ & {$[42]$} \\
\hline Uruguay & $0.35 \mathrm{~m} / \mathrm{s}$ & $\begin{array}{l}\text { MOHID - Water } \\
\text { Modelling System }\end{array}$ & $\begin{array}{l}\text { GEBCO } 30 \text { arc-second and } \\
\text { regional bathymetry charts. }\end{array}$ & [48] \\
\hline $\begin{array}{l}\text { Brazil, Baía de } \\
\text { Todos os Santos }\end{array}$ & $\begin{array}{c}\operatorname{Max} 1.0 \\
\mathrm{~m} / \mathrm{s}\end{array}$ & ROMS & No provided information & [49] \\
\hline $\begin{array}{l}\text { France, W. } \\
\text { Brittany coast. }\end{array}$ & $\begin{array}{l}\text { From } 1 \mathrm{~m} / \mathrm{s} \\
\text { to } 4 \mathrm{~m} / \mathrm{s}\end{array}$ & Data Analysis & No provided information & {$[50]$} \\
\hline $\begin{array}{l}\text { Channel Islands, } \\
\text { UK and France. }\end{array}$ & $\begin{array}{l}>2.5 \mathrm{~m} / \mathrm{s} \\
\text { mean } \\
\text { spring tide }\end{array}$ & TELEMAC 2D & T-Carta $90+$ GEBCO & [19] \\
\hline $\begin{array}{l}\text { France, English } \\
\text { Channel. }\end{array}$ & $\begin{array}{l}1.5 \mathrm{~m} / \mathrm{s} \\
\text { average }\end{array}$ & MARS2D & $\begin{array}{c}\text { Bathymetry provided by } \\
\text { SHOM-IFREMER }\end{array}$ & {$[60]$} \\
\hline
\end{tabular}


668 Example of the steering file used in the model simulation within the Gulf of California created in

669 TELEMAC 2D. A brief explanation of the purpose of the variables is provided, in brackets, for each line.

670

containing mesh coordinates)

BINARY DATABASE 1 FOR TIDE

$$
={ }^{\prime} . / \mathrm{tpxo} / \mathrm{h} \_ \text {tpxo } 7.2^{\prime} \text { (forcing file elevation) }
$$
constituents from the one read in input files linked to keywords BINARY DATABASE 1 FOR TIDE and BINARY DATABASE 2 FOR TIDE.)

682

RESULTS FILE $=$ 'Results_33days_BCF_CICESE.slf' (Binary results file)

683

684

l

GENERAL OPTIONS

685

VARIABLES FOR GRAPHIC PRINTOUTS $=\mathrm{U}, \mathrm{V}, \mathrm{S}, \mathrm{H}, \mathrm{B}(\mathrm{U}, V=$ Flow speeds, $H=$ Depth, $S=$ Free

surface, $B=$ Bottom friction)

689

TIME STEP

$$
=10 \text { (Seconds) }
$$

NUMBER OF TIME STEPS

$=285120 / 33$ days every 10 seconds (Total

690 duration of simulation)

691 NUMBER OF FIRST TIME STEP FOR GRAPHIC PRINTOUTS $=1$ (Period between output to

692 results file (time steps))

693

GRAPHIC PRINTOUT PERIOD

$=60($ Period between output to results file (time steps) $)$

694 LISTING PRINTOUT PERIOD

$=10($ Period between listing file output (time steps)

695 MASS-BALANCE

$=$ YES (Determines whether or not the mass-balance over

INITIAL CONDITIONS

699

$$
=0 ; 0 ; 0 \text { (Initial simulation time) }
$$


define initial water depth conditions.)

704

705

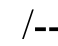

706

\section{BOUNDARY CONDITIONS}

708

OPTION FOR LIQUID BOUNDARIES velocities)

719 generating potential) coordinates)

HYDRODYNAMICS-PHYSICAL SETUP

\section{LAW OF BOTTOM FRICTION} model bed friction over the whole domain )

733 FRICTION COEFFICIENT

734 applied uniformly over the domain)

735 TURBULENCE MODEL

736 Idomain, Smagorinski model.)

\section{DIFFUSION OF VELOCITY}

\section{VELOCITY DIFFUSIVITY}

$$
\begin{aligned}
& =4 \text { (Number } 4 \text { correspond to manning law that was used to } \\
& =0.030 \text { (Friction coefficient relating to Manning law friction } \\
& =4 \text { (Constant turbulent viscosity throughout the } \\
& =\text { YES } \\
& =1 . E-6 \text { (for option } 4 \text {, the keyword VELOCITY DIFFUSIVITY must }
\end{aligned}
$$
be the value of molecular viscosity $(10-6 \mathrm{~m} 2 / \mathrm{s})$ because it is used as such in the turbulence model.) 

are used to solve the advection step, the first number indicates the variable $U$ and $V$ (velocity components and the number 5 indicated the method that is PSI distributive scheme, mass-conservative (mandatory for $\mathrm{H}$ ),

\section{SUPG OPTION}

748

749

750

751

752

753

754

755

756

757

758

759

760

761

762

763

764

765

766

767

768

769

770

771

772

773

774

775

776

\section{SOLVER}

step)

$$
\text { /- }
$$

\section{ZERO}

TIDAL FLATS

shallow regions) regions) the boundary points)

\section{MATRIX STORAGE}

storage. It is strongly recommended to use the default value as 3)

$$
\begin{aligned}
& =0 ; 0 \text { (Upwind scheme, no upwinding) } \\
& =3 \text { (keyword configures the type of matrix }
\end{aligned}
$$$$
=0.6
$$$$
=2 \text { (Uses velocity from momentum }
$$

$$
\text { TREATMENT OF THE LINEAR SYSTEM }
$$
equation rather than continuity equation to improve computational efficiency) TREATMENT OF FLUXES AT THE BOUNDARIES $\quad=1 ; 1$

$$
\text { INFORMATION ABOUT SOLVER= YES }
$$

\section{MAXIMUM NUMBER OF ITERATIONS FOR SOLVER $=100$}

$=3$ (Conjugate gradient method for the /hydrodynamic propagation step)

SOLVER ACCURACY

= 1.E-6 (Accuracy during propagation

NUMERICAL OPTIONS

$=1 . \mathrm{E}-10$

$=$ YES (Enables wetting and drying in $=1$ (Enables wetting and drying in shallow $=2$ (specifies the type of treatment of the TREATMENT OF NEGATIVE DEPTHS tive depth, 2 : Flux control). negative depths, there are three options: 0 :
CONTINUITY CORRECTION

$=$ YES (corrects velocity particularly in

\section{DISCRETIZATIONS IN SPACE}

$=11 ; 11$ (binary triangle 4 node triangle) velocity and linear depth)

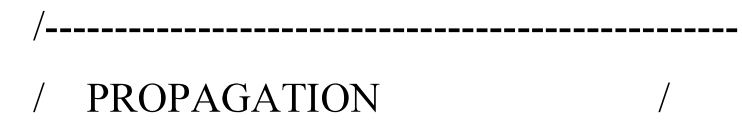


777 IMPLICITATION FOR DEPTH

778 time)

779 IMPLICITATION FOR VELOCITY

780 time)

781 IMPLICITATION FOR DIFFUSION OF VELOCITY

782 equation is not applied)

783 MASS-LUMPING ON H

784 accelerate the computational simulation as well as consider the setting values of $H$ within the model)

785 \&FIN (end of the steering file)
$=1$. (To account for semi-implicit discretization of

$=1 .($ To account for semi-implicit discretization of $=1 .($ Recommend as default where the wave

$=1$. (This number refers to the method to

786 